\title{
THE EROSION OF INDIAN RIGHTS, 1950-1953: A CASE STUDY IN BUREAUCRACY
}

\author{
FELIX S, COHEN†
}

Ovr 450,000 American citizens ${ }^{1}$ who are members of Indian tribes are probably the only racial group in the United States whose rights are more limited in 1953 than they were in 1950. The erosion of Indian rights in this period and the factors which contributed to that erosion can be fairly evaluated only if we also view the background of Indian progress during the 21-year period from 1929 to 1950. During that period more than a score of discriminatory restrictions upon Indians were abolished; the size of Indian landholdings increased, instead of decreasing, for the first time in American history; the real income of most Indian families doubled or tripled; and the Indian death rate was cut in half. During that period the Bureau of Indian Affairs was a leading participant in almost every battle for Indian rights.

Beginning with the administration of Commissioner Rhoads, appointed by President Hoover in 1929, the Bureau of Indian Affairs inaugurated a determined effort to do away with the major legal discriminations from which Indians then suffered. The Meriam Report, ${ }^{2}$ published in 1928, at the request of Secretary of the Interior Hubert Work, pointed to the two most serious deficiencies in Indian administration: the exclusion of Indians from the management of their own affairs, and the poor quality of public services (especially health and education) rendered by public officials not responsible to the Indian people they served.

From 1930 to 1950, the Bureau respected the right of Indians to hold their own elections and to select their own representatives and attorneys. ${ }^{3}$ Two or

Tisiting Lecturer in Law, Yale Law School.

Factual information presented in this article for which no specific authority is cited has been gathered in the author's present capacity as general counsel to several Indiau tribes and to the Association on American Indian Affairs, Inc., and in his earlier capacity as counsel to the Secretary of the Interior and as Associate Solicitor and Chairman of the Board of Appeals of the Interior Department.

1. All American Indians, whether or not living on a reservation, who had not previously been accorded that status, were declared to be citizens of the United States. $\mathbf{4 3}$ STAT. 253 (1924), 8 U.S.C. $\S 601$ (1946). The special laws and regulations relating to Indians are analyzed in CoHEn, Handbook of Federal Indian Law (4th ed. 1945) (cited hereinafter as COHEN, HANDBOOK).

2. Merians \& Assoctates, The Problens of Indian Administration (1928). This report and other matters briefly mentioned in the following paragraphs are discussed in more detail in CoHen, HANDBook 26-7, 83-7.

3. See, e.g., Memorandum of Solicitor, Department of Interior, Jan, 23, 1937, in which it is declared: "A consideration of the general background and purpose of the Indian Reorganization Act [48 STAT. 984 (1934), 25 U.S.C. $\$ \$ 461$ et seq. (1946)] leaves no doubt that the purpose of the statutory provision in question was to increase the scope 
three slips from this standard may be found in this 20 year period, but the whole direction of Indian administration was towards increasing freedom.*

In 1932, Congress passed the famous Leavitt Act," authorizing cancellation of a mass of unjust debts that had been fastened on Indians by past administrations for wasteful and unjustified projects never authorized by the Indians charged.

In 1934, all administrative restrictions upon Indian freedom of religion were repealed by Secretary Ickes and Commissioner Collier; orders forbidding use of Indian languages by Indian school children were also repealed." In the same year, Congress abolished the dictatorial powers of the Indian Bureau to issue passports for the Indian country and to remove critics of the Indian Bureau from Indian reservations, thus giving Indians the same rights of association enjoyed by other races. ${ }^{7}$

of responsibility and discretion afforded the tribe in its dealings with attorneys." In line with Solicitor Margold's opinion are the Interior Department regulations governing the employment of attorneys by Indians, approved May 2, 1938, by Assistant Secretary Osaar L. Chapman, 25 CODE FED. REGS. \$15.1-15.25 (1938).

4. See The NiEw Day for the Ixdaxs (1938). This was a non-partisan appraisal of Indian progress published under the sponsorship of $\mathbf{5 0}$ eminent editors, cducators, churchmen, writers, and scientists interested in Indian prohlems. The survey presentel the following contrast between Indian rights in 1938 and Indian rights as they had existod ten years or more before that date:

\section{RigHTs}

The Old

Rights of Indians almost solely dependent on the Indian Bureau, which maintained itself as a monopoly in Indian administration. Tribal self-government destroyed. Historic policy of breaking up Indian cultural, social and economic life in favor of absorption by the dominant white population.

No legal assurance of civil liberties for Indians. Indians subject to arrest, trial and imprisonment by Indian Service offcials and by judges controlled by reservation superintendents.

Indian Bureau, through good administrations and poor, dealt with Indians istdividually, on paternalistic basis.
The Neri
Indians granted fundamental rights en= joyed hy white citizens; power of Indian Bureau over Indians (tribal funds, civis authority) curbed Cooperation gained from Soil Cunservation Service, Social Security Administration, Civilian Conservation Corps, Worls Progress Administration, state boards of clueatiun. state welfare agencies, etc.

Right of Indians to their oun langusges, ceremunies, arts, and traditions respected and encouraged.

Gag and sedition laws repealed. Religisus and cultural liberty affirmed. System of justice for Indians reorganized, saieguarded from official control of Indian courts, whose jurisdiction is careiull: defined.

Indian Bureau fosters demoeratic principles and the right to negotiate through representatives of Indians' own choosing.

5. 47 StAT. 564 (1932), 25 U.S.C. $\$ 386(a)$ (1946).

6. See Conen, HandBook 176 n.348.

7. 48 Stat. 787 (1934). See also, Annotation, 25 U.S.C.A. § 171 (Supp. 1951). 
In the same year, Indians won from Congress the right to establish corporations and councils with powers not subject to administrative revocation; gained the right to veto any disposal of tribal property by the Indian Bureat1; secured authorization for a $\$ 10,000,000$ credit fund $^{8}$ to be administered by the Indians themselves; and won a statutory exemption from civil service requirements for all jobs in the Indian Service. ${ }^{9}$

In 1935, Congress set up a special agency to help Indians market the products of their native arts and crafts, remnants of a culture that had survived a century of Bureau efforts at eradication. ${ }^{10}$ In 1936, Congress acted to grant tax exemption to Indian homesteads purchased with Indian trust funds. ${ }^{11}$

Beginning in 1936, six states which had always denied the franchise to Indians retreated from this position. The last two holdout states, Arizona and New Mexico, yielded in 1948 to adverse decisions, in suits brought by Indians. ${ }^{12}$ In each case Indians secured the right to serve on juries along with the right to vote.

In 1938, the Supreme Court recognized that minerals and timber on Indian reservations belonged to the Indians and not to the Government. ${ }^{13}$ In the same year Congress acted to assure Indians of the right to lease their own minerals. ${ }^{14}$

In 1940, Congress passed legislation to refund to Indians taxes that they had been forced to pay when thousands of tax-exempt trust estates were terminated without Indian consent under the "forced patent" policy of Commissioners Sells and Burke. 15

In 1941, the Supreme Court upheld the right of Indians to lands which they had occupied from time immemorial, even in the absence of formal treaties or acts of Congress. ${ }^{16}$ In the years from 1942 to 1946, this principle was vigorously applied by Secretary Ickes, Commissioner Collier, Commis-

8. This fund was later expanded by additional authorizations to cover Oklahoma tribes and the Navajo and Hopi Indians.

9. 48 StAT. 984 (1934), 25 U.S.C. $\$ 861$ et seq. (1946); see also 49 STAT. 1967 (1936), 25 U.S.C. $\$ \$ 501$ et seq. (1946).

10. 49 StAT. 891 (1935), 25 U.S.C. $\$ 305$ et seq. (1946).

11. 49 Stat. 1542 (1936), as amended, 50 Stat. 188 (1937), 25 U.S.C. $\$ 412$ (a) (1946).

12. Harrison v. Laveen, 67 Ariz. 337, 196 P.2d 456 (1948) ; Trujillo v. Garley, statutory three-judge federal court, New Mexico (1948) (unreported).

13. United States v. Shoshone Tribe, 304 U.S. 111 (1938). The scope of this decision is discussed in Cohen, Original Indian Tille, 32 Mins. L. REv. 28, $54-5$ (1947).

14. 52 StAT. 347 (1938), 25 U.S.C. $\$ 396$ et seq. (1946).

15. 54 Stat. 298 (1940), as amended, 56 Stat. 87 (1942), 25 U.S.C. $\$ 352$ (c) (1946). See note 99 infra.

16. United States v. Santa Fe Pacific R.R., 314 U.S. 339 (1941). See discussion in Cohen, supra note 13 , at 55-6. 
sioner Brophy, and Acting Commissioner Zimmerman to protect the property rights of Alaskan natives. ${ }^{17}$

In 1946, President Truman signed his name to the Indian Claims Commission Act, which gave Indians the right to collect just debts from the United States Treasury, a right that people of other races had been able to pursue in the Court of Claims for 83 years. ${ }^{18}$

In 1948, another long-standing discrimination against Indians was lifted when the United States Supreme Court held restrictive covenants against Indians, Negroes, and other so-called "non-Aryans" unenforceable.10

In 1949, following a year of Indian litigation, Arizona and New Mexico abandoned their policy of excluding Indians from old-age assistance, aid to the blind, and aid to dependent children, thus allowing Indians, for the first time, to enjoy in every state the same social security rights enjoyed by every other race. ${ }^{20}$

In 1950, twenty-four tribes launched an appeal to the White House against the Department of Agriculture's discriminatory exclusion of Indians from the scope of farm housing loans and grants. A year later this appeal brought a reversal of the ruling. ${ }^{21}$

There were still, in 1950, grievances and discriminations, but in almost every case the Indians felt that they could count on the support of the Indian Bureau and the Interior Department to do away with these survivals of ancient prejudice and hostility.

In appraising changes that have occurred in the Indian field since May. 1950, when Dillon S. MYyer took office as Commissioner of Indian Affairs, three fields call for special attention: (1) restrictions upon freedom which apply only to Indians; (2) restrictions upon Indian control of Indian property; (3) organic changes in the power structure of the Bureau of Indian

17. See, e.g., Public Land Order 128, May 22, 1943, issued by Secretary Ickes under authority of 49 STAT. 1250 (1936), 48 U.S.C. \$358(a) (1946), which established an Indian reservation on Kodiak Island. This order is discussed in Hynes v. Grimes Paelang Co., 337 U.S. 86 (1949).

18. 60 STAT. 1049 (1946), 25 U.S.C. $\$ 70$ (a) (1946). This Act allowed suits in the Court of Claims for wrongs consummated after August 13, 1946. For the adjudication of wrongs previously consummated, Congress set up a special Indian Claims Commission with jurisdiction to consider cases based upon violation of laws, treaties, or standards of "fair and honorable dealings." The original bar to the prosecution of suits by Indian tribes against the United States in the Courts of Claims was contained in $\$ 9$ of the Act of March 3, 1863, 12 Stat. 765, 767 (1863).

19. Hurd v. Hodge, 334 U.S. 24 (1948); Shelley v. Kramer, 334 U.S. 1 (1948). The complaint in the former case indicated that the person against whom the restrictive covenant was invoked was a Mohawk Indian.

20. Mapatis v. Ewing, filed in the United States District Court for the District of Columbia on September 21, 1948; complaint vithdrawn when Arizona agreed to malse social security payments to Indians.

21. 16 FED. REG. 6713-15 (1951). 
Affairs which underlie the changes in the boundaries of Indian rights and liberties.

\section{Restrictions Upon Indian Freedom}

According to the statutes, American Indians are entitled to exercise all the rights of citizenship. ${ }^{22}$ But these rights are limited, in practice. by more than 2200 regulations now in force issued by the Commissioner of Indian Affairs. Many regulations, perhaps most, cite as their chief or sole authority Section 1 of the Act of July 9, 1832, ${ }^{23}$ which establishes the office of Commissioner of Indian Affairs and vests in that office "the management of all Indian Affairs." Similar housekeeping statutes vest responsibility for "matters respecting foreign affairs" in the State Department," and the duty to "develop) ... the transportation facilities of the United States" in the Department of Commerce. ${ }^{25}$ These statutes have not been construed to give the Secretary of Commerce any power to improve the services rendered by our railroads or to give the Secretary of State any power over foreign nations. But Indians for some decades have had neither armies nor lawyers to oppose increasingly broad interpretations of the power of the Commissioner of Indian Affairs, and so little by little "the management of all Indian Affairs [of the Federal Government]" has come to be read as "the management of all the affairs of Indians." This trend towards enlarged bureau power was accelerated in the second half of the nineteenth century by the influx of former army officers into the personnel of the Indian Bureau. Administrators accustomed to exercising the powers of a military government were impatient of legal restraints as they undertook to govern all aspects of the lives of their subject peoples.

While there are some cases indicating that the Bureau's broad construction of its organic act would not be sustained if legally challenged, ${ }^{20}$ administrations which sought to restrict Indian freedom have generally made sure that Indian tribes were not permitted to employ attorneys who might be inclined to challenge such assaults; those administrations which allowed Indians full freedom to hire lawyers did not make any assaults on Indian freedom that such lawyers could challenge.

The process of piecemeal enlargement of Federal Government attempts to control the conduct of Indians evoked the wonder expressed by a puzzled Indian Commissioner in his Ammual Report for 1892 :

"Appointed at first in the capacity of a commercial agent or consul of the United States in the country of an alien people, the Indian

22. 43 STAT. 253 (1924), 8 U.S.C. $\$ 601$ (1946). See Annotation, 8 U.S.C.A. $\$ 601$ (1946).

23. Rev. Stat. §463 (1875), 25 U.S.C. \$2 (1946).

24. Rev. Stat. $\$ 202$ (1875), 5 U.S.C. $\$ 156$ (1946).

25. 32 Stat. 826 (1903), 5 U.S.C. $\$ 596$ (1946).

26. See United States v. George, 228 U.S. 14 (1913); Jones v. Meehan, 175 U.S. 1 (1899) ; Leecy v. United States, 190 Fed. 289 (8th Cir. 1911), app. dismissed, 232 U.S. 731 (1914); and other cases cited in CoHEN, HANDsook 101-103. 
agent ... has developed into an officer with power to direct the affairs of the Indians and to transact their business in all details and in all relations. This is a very curious chapter in our history. There is a striking contrast between 'ministers plenipotentiary,' appointed by the United States to treat with powerful Indian nations, and an army officer, with troops at his command, installed over a tribe of Indians to maintain among them an absolute military despotism. Yet our policy of dealing with them has swung from one of these extremes to the other in a strangely vacillating way."

The following incidents indicate the most recent of these vacillations.

\section{Freedom of Elections}

In a democracy any interference with the right to vote is, of course, subversive of all other rights, and the general trend throughout the nation has been to diminish such interference. 28 Quite to the contrary, however, is the recent record in the Indian country. During the period 1950-1952 interference with the right to vote increased, chiefly along two lines: the use of federal funds to influence local elections, and direct interference with local election arrangements.

Use of federal funds. A notable instance of the use of federal funds to influence local Indian elections occurred on the Blackfeet Reservation during the June, 1950, tribal election. Thirty-six pages of mimeographed materials attacking certain candidates for local tribal office, charging them with various "criminal" and "illegal" acts (none of which were ever prosecuted and most of which were later shown never to have occurred) were prepared by Government employees at Government expense on Government paper and Government mimeograph machines. Hundreds of copies of this campaign literature were circulated by Government employees on the reservation during the two weeks before the election. The Association on American Indian Affairs wired Secretary Oscar L. Chapman on June 17, 1950, to inquire whether the circulation of such materials was known and approved by the Secretary of the Interior. This question was answered in the affirmative.?

27. REP. COASAI'R OF INDIAN AfFATRS, 1S92, p. 24 (1892).

28. Smith v. Allwright, 321 U.S. 649 (1944); Lane v. Wilson, 307 U.S. $26 S$ (1939); Nixon v. Herndon, 273 U.S. 536 (1927).

29. Some months later Senator Chavez commented on this situation in the following terms:

"But I do not think it is the business of the Indian Bureau to participate in matters of that nature. That is up to the individuals in the individual communities. I do not blame the Indians for resenting that kind of activity.

"The Indian Bureau has enough to do without mixing up in lowal politics or spending the money of the Indian Bureau for that particular purpose.

"They get little enough money-so they say, the Bureau itselfwithout using the money over there to control an election either 
Such use of federal funds to influence local Indian elections quickly became accepted Departmental practice after June, 1950. In the Blackfeet referendum election of May, 1952, and the Choctaw referendum election of July, 1952, letters from Interior officials on the merits of referendum issues (as seen by the Indian Bureau) were distributed at Government expense with a view to influencing voters.

The Indian Bureau defends.its use of federal funds to "enlighten" Indian voters on the ground that it has a trustee's obligation to see that Indians have a proper understanding of the issues on which they vote. ${ }^{30}$ But the assumption of superior enlightenment concerning election issues on the part of Government officials runs counter to our American concept of popular government.

Direct interference. Similarly, direct interference with local elections for local offices has increased in frequency during the past three years. When the Blackfeet Tribe held a referendum election on May 9, 1952, on a proposed amendment to the tribal constitution, the Interior Department ran a rival election, managed by Indian Bureau employees; called out its special Bureau police force; closed down one or more tribal polling places; seized tribal funds, without tribal consent, to pay some of the expenses of the Bureau election (notwithstanding Secretary Chapman's assurance that no such action was contemplated); and, in order to validate its own election results, tried to strike more than 1,000 Blackfeet names from the list of eligible voters. This last move was eventually held by the Solicitor of the Interior Department to be illegal, and so the Bureau's election results were declared invalid. But the Bureau continues to insist that it has the right to run future tribal elections even where, as in the Blackfeet case, the tribal constitution provides that all local elections are to be supervised by the Indians themselves. ${ }^{31}$

At San Ildefonso Pueblo, in New Mexico, the Indian Bureau seized control of valuable lands and proceeded to dispose of the resources of the Pueblo without statutory authority, on the pretext that the Pueblo had failed to elect

amongst the Blackfeet or the Lagunas or Apaches, or the 17 pueblos of my State."

Hearings before Senate Appropriations Committee on H.R. 3790, 82d Cong., 1st Sess. 2200 (1951).

30. Evidence of Bureau activity in "explaining" issues to the Indians may be found in circulars such as that signed and distributed by Blackfeet Superintendent Guy Robertson, under date of April 30, 1952 .

31. Article IV, $\S 3$ of the Blackfeet Tribal Constitution, adopted pursuant to the Indian Reorganization Act and approved December 13, 1935, provides: "All elections shall be held in accordance with the rules and regulations laid down by the tribal council, or an election board appointed by the tribal council." The Indian Bureau, disregarding its own practice of at least 17 years, claimed that "all elections" did not include referendum elections and asserted an "implied power" in itself to run tribal elections notwithstanding the language of tribal constitutions. Letter of Blackfeet Superintendent Guy Robertson to Area Director Paul L. Fickinger, dated January 24, 1952. 
a Governor. In fact, the elected Governor of the Pueblo is recognized by all the other Pueblos, by the public, and by all of the members of the Pueblo except for a few beneficiaries of the Bureau's illegal acts.

\section{The Right to Counsel}

For Indians, as for other underprivileged groups, denial of the right to independent counsel means undermining of all the rights which require independent counsel for enforcement. When Commissioner Myer promulgated a set of proposed regulations to control both the selection of attorneys by Indians and the activities of attorneys so selected, the protests from Indians and nonIndians alike were so vigorous that Secretary Oscar L. Chapman called a public hearing on the proposal. ${ }^{32}$ At this hearing, 4 witnesses appeared, including 24 representatives of more than forty Indian tribes; a special committee of the American Bar Association, along with 17 other non-Indian representatives, was also heard. Each of the witnesses opposed the proposed regulations as an unwarranted infringement on the right of Indians to representation by counsel of their own choosing. ${ }^{33}$ The final report of the special committee of the American Bar Association declared: "... [T] The Committee has been unable to find evidence of any necessity to turn the clock backward so as to subject the Indian tribes to the minute and detailed controls which are prescribed in the proposed regulations." 34

On January 24, 1952, Secretary Chapman rejected Commissioner Myer's proposed regulations. Despite this rejection, Commissioner Myer continued to deny thousands of Indians the right to employ attorneys of their own choice, on the theory that the regulations rejected by his superior, Secretary Chapman, were merely declaratory of existing practice and that he was merely carrying out the prior existing practice. ${ }^{35}$ The fact remains, however, that during more than a decade before Mr. Myer took office no Indian tribe had

32. Commissioner Myer found authority for his proposed regulations in 17 Srnx. 136 (1872), 25 U.S.C. $\$ 81$ (1946), which placed certain restrictions upon the employment of attorneys in matters relating to the lands or claims of "Indians not citizens of the United States." Apparently, no consideration was given to the limitations upon that law contained in 43 Stat. 253 (1924), 8 U.S.C. $\$ 601$ (1946), or 48 StAT. 984, 25 U.S.C. $\$ \$ 461,467$ (1946).

33. Among the organizations which condemned Commissioner Myer's proposed regulation were the Association on American Indian Affairs, Inc, Indian Rights Association, American Civil Liberties Union, National Association for the Advancement of Colored People, American Jewish Congress, Congress of Industrial Organizations, United Automobile Workers, and the Women's International League for Peace and Freedom. For typical newspaper criticisms of the proposed regulation see Editorial, $A$ Baelatard Stch, N.Y. Times, Oct. 15, 1951; Editorial, Let Indians Choose thcir Ouni Counsel, Washington Star, Jan. 6, 1952; Editorial, Indian Cotussel, Washington Post, Aug. 29, 1952.

34. Hearings on Proposed Regulations to Gopers Imblas Trmal Atromasey Co:TRACTS, TRANSCRTPT 1995 (1952).

35. The Commissioner has adopted this position despite the fact that some of the grounds advanced to disapprove contracts previously had been held invalid insofar as 
ever been denied the right to retain as its attorney any lawyer in good standing at the bar. Since Mr. Myer took office more than forty Indian tribes have complained of Bureau interference in the exercise of this right. The Secretary on January 24, 1952, announced appointment of a committee to look into this problem. At last reports, the committee had never met.

\section{Freedom of Speech}

The right to speak one's mind freely is so widely taken for granted in American life that it is inconceivable to most of us that anybody could have his bank accounts impounded as a penalty for criticizing the operations of a government bureau. Yet when the Oglala Sioux Tribe on September 28, 1950, petitioned Congress to cut wasteful expenditures of the Indian Burean in its so-called "extension service" in South Dakota, the Indians were advised that $\$ 140,000$ of credit funds allocated to the tribe several months earlier would be "frozen" until the tribe withdrew its criticisms. ${ }^{30}$ Of course, there was no legal authority for any such action, any more than there would be for the freezing of the bank account of a non-Indian. But the Indian funds were in the possession of federal officials, and possession is at least nine points of the law. Even a non-Indian confronted by his banker with a "freeze order" from the Federal Reserve Board based upon a report by the Post Office Department and the Federal Bureau of Investigation that the depositor was engaged in subversive activities might have a hard time fighting his case through the courts with the world's largest law office on the other side of the case. Indians who are unable to employ counsel of their own choosing face even tougher odds in such a situation.

\section{Freedom from Legal Discrimination}

For a long time Indians have been asking for the repeal of various ancient statutes, mostly dating from the era of Indian wars, which make it illegal for Indians to buy liquor or ammunition or to sell various classes of livestock, agricultural implements, or cooking utensils. ${ }^{37}$ When the Indians of Arizona and Montana testified in support of bills repealing these ancient discriminations, sponsored by Representative Patten of Arizona and Senators Ecton

\footnotetext{
"applied retroactively so as to strike down contracts negotiated and entered into in good faith by Indian tribes and attorneys under existing policies." Memorandum from Special Departmental Appeals Committee to Secretary Chapman, Feb. 28, 1951.

36. Details of these threats are given in the statements of Council Secretary Eaglebull and Commissioner Myer on Feb. 8 and Mar. 9, 1951. Hearings before Housc Appropriations Committee on Interior Department Appropriations for 1952, 82d Cong., 1st Sess. 1243,1263 (1951).

37. Rev. Stat. \$\$467, 2136 (1875), 25 U.S.C. \$266 (1946); Rev. StAT. \$2138 (1875), as amended, 18 U.S.C. $\$ 1157$ (1946) ; REv. STAT. \$2135 (1875), 25 U.S.C. $\$ 265$ (1946) ; Rev. Stat. $\$ 2139$ (1875), as amended, 18 U.S.C. $\S \S 1154,1156$ (1946); 23 STAT. 94 (1884), 25 U.S.C. $\$ 195$ (1946).
} 
and Murray and Representative D'Ewart of Montana, 39 the Indian Bureau testified in opposition to these measures.

The arguments presented by the Indian Bureau on such proposed bills vary from bill to bill, but the upshot of the argument is always the same. Every anti-discrimination bill so far introduced on behalf of Indians has been opposed by the Bureau. Sometimes the argument is that the discriminatory laws to which the Indians object-e.g., the law which requires Indians to secure the approval of Government officials before selling their own cattle, even after they have paid off any liens or chattel mortgages-are really necessary for the Indians' protection. Sometimes the argument is that while the objective of the bill is sound, it should be pursued in some other way which in fact is totally impractical. This technique is applied particularly to defeat the legislative proposals of the Indians of Montana and Arizona, who have well-organized state-wide intertribal councils and are therefore able to reach general agreements on matters of common concern. When these Indians succeed in getting their Democratic and Republican Senators and Representatives to introduce legislation to repeal old laws which make it illegal for Indians to buy ammunition or sell clothing, the Indian Bureau opposes the legislation on the ground that any such measure should not be limited to Montana or Arizona-knowing full well that it would take many months, or perhaps years, to secure agreement on such bills among all the tribes in other states, and that it would be practically impossible to secure passage of this type of nation-wide legislation so long as there are tribes or Congressmen who have not yet had time or inclination to study the subject of legal discrimination.

The Indian Bureau's activities in opposition to the outright repeal of the discriminatory laws forbidding the sale to Indians of non-poisonous alcohol (even in the form of vanilla extract or tonic) are particularly unwholesome. In this situation, the Bureau, realizing how strongly Indians (including nondrinkers) resent the discrimination, insists upon using that resentment as a motive power to achieve acceptance of a wholly unrelated program, the abolition of tribal self-government. In furtherance of this policy, representatives of the Commissioner have travelled throughout the country offering Indians freedom from liquor restrictions if they will only give up their local courts and tribal police and accept state criminal jurisdiction. All the tribes of Montana have disapproved the Indian Bureau's "tie-in" sale of liquor; they insist that the repeal of discriminatory liquor laws in Montana "should not be made conditional upon state taxation, the elimination of tribal law and order codes, or any other surrender of Indian rights."30

38. S. 2620, 82d Cong., 2d Sess. (1952), introduced by Senators Ecton and Murray on Feb. 7, 1952; H.R. 6238, s2d Cong., 2d Sess. (1952), introduced by Representative D'Evart on Jan. 28, 1952; and H.R. 6703, 82d Cong., 2d Sess. (1952), introluced by Representative Patten on Feb. 19, 1952.

39. Resolution No. 6, November 27, 1951, Proceedings of Mfeetings of the Miuntana Inter-Tribal Policy Board, Helena, Montana, November 26-7, 1951, p. 9. It shuuld te 


\section{Access to Hospitals}

Pursuant to a long series of treaties and agreements, the Federal Government has built a number of hospitals for various Indian tribes. Indians have contributed lands, funds, and labor to the construction of these hospitals. On May 7, 1951, Commissioner Myer testified in favor of legislation to vest in the Secretary of the Interior (in reality, the Commissioner of Indian Affairs) the power to give away such hospitals to local political bodies or private parties without the consent of the Indians concerned. Representatives of the Association on American Indian Affairs and various Indian tribes, opposing Commissioner Myer's proposal, urged that Indian consent be made a prerequisite of such a transfer. ${ }^{40}$ Congress rejected Commissioner Myer's request and adopted the amendment urged by the Indians and their friends, which is now embodied in Public Law No. 291, approved April 3, 1952. Commissioner Myer thereupon drafted a series of bills which would eliminate the requirement of Indian consent.11

Commissioner Myer's opposition to the rebuilding of the Papago Hospital - the only hospital on a 2,855,000 acre reservation, which burned down in 1947-and his closing down of small hospitals and clinics on various other reservations probably reflect the Commissioner's belief 'that Indians should not be encouraged to remain on reservations and that better reservation health facilities would constitute such encouragement. For example, in explaining a plan to remove various reservation officials from a South Dakota reservation, and locate them in another part of the state, notwithstanding the protests of the Indians, Commissioner Myer wrote:

"The main overall reason we favor this is that we think the time is drawing near when Indian agencies, as such, located out on the reservations, should become unnecessary and should cease to exist. The Indians of South Dakota, I am sure you will agree, are at a point where they should be mingling more and more with the nonIndian population instead of living as a tight, close-knit group within the mental and physical confines of the reservation." 42

In accepting the cliche that portrays an Indian's relation to his reservation as one of mental and physical confinement, Commissioner Myer forgets that

noted in this regard that in 1946 the Indian Bureau sponsored a bill (S. 2159) to abolish discriminatory liquor laws without affecting tribal self-government. REP. SEC'Y of THE INTERTOR, 1946, p. 381 (1947).

40. This testimony was presented before hearings of the House Subcommittec on Indian Affairs concerning H.R. 1043, on May 7, 1951. Commissioner Mycr's testimony appears in the record of the hearing, which has never been printed.

41. H.R. 7490, H.R. 7491, S. 3005, introduced April 10, 1952, in 82d Cong., 2d Sess., provide in $\$ 7$ for disposition of hospitals and other federal Indian installations in California without Indian consent. S. 3004, introduced on the same day, contains a similar provision for Oregon. It is reported that similar bills have been drafted for other states with Indian reservations.

42. Letter of Commissioner Myer, dated October 19, 1951. 
at least since 1879 Indians have been free to leave their reservations when they pleased. The fact is that Indians still largely reject the way of life represented by Gypsies and semi-nomadic Government officials. They still feel deeply attached to the lands their grandfathers reserved for themselves and their children's children. And most Indians, like most of their neighbors, would like to see schools, hospitals, and other public services close to their homes.

\section{Freedom of Religion}

Where native religious customs interfere with administrative convenience, Commissioner Myer has taken the position that Indian Bureau officials regularly maintained in the 18S0's and 1890's: native custom must give way. For example, at one of the Rio Grande Pueblos, where ancient custom requires that no white person remain within the Pueblo at certain ceremonials, the Indian Bureau now insists that its employees will remain on the Pueblo grounds notwithstanding the objection of the Indian landowners to their presence. ${ }^{43}$ The outcome of this controversy is still in doubt.

\section{Freedom from Arrests, Searches, and Seizures Without Warrant}

A bill to authorize employees of the Indian Bureau to carry arms and to make arrests, searches, and seizures, without warrant, for violation of Bureau regulations, on or off Indian reservations, ${ }^{41}$ provoked a storm of protests from Indian tribes, civic organizations, and editorial writers throughout the country. ${ }^{45}$ Opponents of the measure pointed out that Indians are now subjected to more than 2200 regulations applicable to them just because they are Indians, in addition to all regulations applicable to them as taxpayers, citizens, etc., and that not even the F.B.I. or the United States marshals have general power to make arrests for violations of administrative regulations. ${ }^{\text {to }}$

43. Letter of Commissioner Miyer, dated October 17, 1951, and letter of the Albuquerque Area Director, dated March 6, 1952.

44. H.R. 6035, 82d Cong., 2d Sess. (1952).

45. Typical editorial comments are the following:

"Chronic hardship, lack of schooling and the unrelieved ravages of disease naturally" provoke discontent and criticism among the victims. The bill to authorize the Indian Bureau to make arrests without warrant for violation of Indian Bureau regulations, ete., might fill the jails with complainants, but can hardly remedy conditions and policies which provoke and justify the complaints." New Orleans Times-Picayune, April 18, 1952

"This measure appears to be a bald-faced attempt by the Indian Bureau to seire dictatorial powers. The right to be secure from arrest without warrant is cne that has deep roots in American civil rights. To deprive the first Americans of this privilege is irony indeed." Gallup, N.M., Independent, April 16, 1952.

"It is amazing that an agency of our Government, for any reason, would put forth such proposals as these. Such a grant to bureaucrats of vast authority over Indians or anyone else in this country hasn't a shadow of justification. It should be rejected." Philadelphia Inquirer, April 17, 1952.

46. The Association on American Indian Affairs observed that "no one would dream of saying that women or veterans should be subject to arrest without warrant or searches 
Commissioner Myer, on the other hand, gave the proposal his full support, and made several speeches and distributed thousands of circular letters charg ing that critics of the measure were either dishonest or dupes of dishonest agitators. ${ }^{47}$ After extensive hearings, the House Judiciary Committee killed the Commissioner's bill.

\section{Freedom in Personal Life}

The extent to which the Bureau of Indian Affairs now seems prepared to supervise the intimate details of an Indian's personal life is indicated by an incident reported to the Senate Appropriations Committee on May 7, $1952: 48$

"Last week a tribal policeman on the Blackfeet Reservation reported that the local superintendent had called him in to see that the Indian men and women at Heart Butte stopped playing the stick games (a sort of aboriginal canasta) not later than six o'clock in the evening. Now of course the Blackfeet Agent and the tribal policeman have no more right to tell adult Indians when to stop playing games and when to go to bed than they have to tell me when I should stop playing poker or chess. Conceding that the Blackfeet Superintendent's intentions are highly moral, is there any reason in the world why the Federal taxpayers should pay for that kind of nonsense? Back in 1923, the Indian Bureau had a lot of regulations like that, providing that Indian dances could only be held once a month 'in the daylight hours of one day in the midweek' and not in March, April, June, July or August, and 'That none take part in the dances or be present who are under 50 years of age. ${ }^{49}$ Many of us thought that we had outgrown this sort of paternalism when Indians became full-fledged citizens in 1924, but if the Indian Bureau is allowed to proceed unchecked there are no limits to what they will spend Federal funds for."

Telling Indians when to go to bed and when to get up is not just a whimsical bit of paternalism. It has deep roots in a long tradition under which Indians for many decades were subjected to arrest and even death ${ }^{50}$ if they did not behave as white officials wanted them to behave.

or seizures by the Veterans Burean or the Women's Bureau for violating the regulations of these Bureaus." New Republic, June 23, 1952, p. 8.

47. In an undated memorandum widely circulated throughout the country in March, 1952, and thereafter, Commissioner Myer described criticism of the bill as "false and malicious," and accused the writers of the criticisms of intending "to spread terror among the Indians."

48. Hearings before Senate Appropriations Committee on Interior Department Appropriations for 1953, 82d Cong., 2d Sess. 840 (1952).

49. Conen, HaNDBOOK 175-6.

50. A Bureau employee who hanged one of his Indian charges made the following comment in his annual report:

"Indians sometimes have to be dealt with severely and promptly. I made no mention of the execution in my report of Indians, as I did not know whether others could see the 
Thus when the Bureau issues an official report telling the Rio Grande Pueblos that their custom of annual elections is causing "much trouble" in the handling of farm machinery ;1 that their communal use of grazing lands is lowering their grazing income ;2 that their individual partitioning of farming lands is lowering their agricultural income; ${ }^{53}$ and that their religious customs are causing them to put "too much labor" on their corn fields, "these official denunciations have a disastrous effect upon Pueblo life quite similar to the probable effect on a non-Indian of a warning cast in similar terms and bearing the imprint of the F.B.I.

From 1930 to 1950 it looked as though we had definitely put an end to such unauthorized authoritarianism on Indian reservations. It now appears that this view was illusory.

\section{Freedom of Opportunity}

Outside of Indian reservations, every local community in the United States tries to give its own young people a fair chance to serve the community in which they have grown up. To this end, most American communities pick: their own teachers, village clerks, policemen, and other public servants, giving a preference to whatever local talent is available. In an Indian community, however, such jobs (unless the pay is too low to attract outsiders) are generally filled, under Washington directives, by persons who come from far distances, who have no familiarity with local conditions, customs, ways, and people, and who often canriot even understand the community's langunge.

necessity for it that I did, and thought it as well to say nothing about it to the authorities at Washington." Rep. Consar's of Indin Afrarrs, 1866, p. 101 (1866).

Killing of Indians by reservation authorities has been justified on the gruund that Indians were resisting lawful authority. See Rep. Cossar's of Indusi AfFans, 1878, p. 30 (1878).

The use of force in seizing Indians to cut of their braids is defended in Res. Cors ' ${ }^{\circ}$ of INDIAN AFFAIRs, 1902, p. 14 (1902).

The Commissioner's Report for 1899 gives the following ascount of the treatment of the Kickapoos:

"In MIay, 1895, the surplus Kickapoo lands were thrown open to white settlement. Neither band of the Kickapoos was in any way prepared to meet this new condition. The white settlers soon stole or robbed them of most of their property. They became the ready: prey of dishonest deputy United States marshals, who upon false charges of selling whiskey arrested and hauled them to the Federal jail by the wagonload. Later, an effort was made by the agent in charge to put their children in school. This the parents resisted, and for such resistance were maimed and beaten by the brutal deputy marshals, who then arrested them for resisting United States officers in the discharge of their duty.' . . " REP. CONIMIR OF INDIAN AFFAIRS, 1899, p. 292 (1899).

51. Pueblo Extension Prograys for 1951, p. 16 (mimeo. 1951), transmitted by Superintendent Hagberg to the Pueblo Governors, Míarch 15, 1951.

52. Id. at 10 .

53. Id. at 17.

54. Id. at 10 . 
This means that natural avenues of public employment in community service are practically closed to members of the community. Congress attempted to end this condition by enacting legislation in 1934 which declared:
"The Secretary of the Interior is directed to establish standards of health, age, character, experience, knowledge, and ability for Indians who may be appointed, zerthout regard to civil-service lazes, to the various positions maintained, now or hereafter, by the Indian Office, in the administration of functions or services affecting any Indian tribe. Such qualified Indians shall hereafter have the preference to appointment of vacancies in any such position."

This congressional direction has been increasingly ignored in recent years. The required standards for the appointment of Indians to all Indian Service positions "without regard to civil-service laws" have been issued only for a handful of minor positions. For more than $90 \%$ of the jobs in the Indian Bureau no special list of qualifications for Indian candidates-required by law-has ever been promulgated. An outstanding reservation superintendent, himself an Indian, was practically hounded to his death with charges and investigations based on the theme that he had given his first loyalty to the Indians he served rather than to his Washington superiors. ${ }^{\text {to }}$ The Indian Bureau continues to proclaim that Indians are accorded preference in employment. Investigation reveals that this means merely that where a number of job applicants receive the same grade on a civil service examination, the Indian applicant will be "preferred" to the non-Indian. This ignores the law which exempts Indians from civil service requirements. It also ignores the fact that Indians, born into a cultural environment that provides less preparation than does non-Indian society for academic degrees and similar civil service requirements, are inevitably handicapped in civil service competition. Exclusion from the possibilities of on-the-job training, which Bureau employment would provide, serves merely to perpetuate this handicap and to lend weight to the Bureau attitude that Indians are "not yet ready" to run their own public services.

\section{Freedom from Unfair Competition in the Use of Indian Resources}

Because of discriminatory restrictions, the vast majority of Indian landowners are barred from using their own land. The reasons given for this

55. 48 Stat. 984 (1934), 25 U.S.C. $\$ 472$ (1946) (emphasis supplied). Beginning in 1834, Congress adopted a series of statutes giving Indians preference in all Bureau positions. See, e.g., 4 STAт. 735 (1834), 25 U.S.C. $\$ 45$ (1946), which provides:

"And in all cases of the appointment of interpreters or other persons employed for the benefit of the Indians, a preference shall be given to persons of Indian descent, if such can be found, who are properly qualified for the execution of the duties."

These statutes, however, remained dead letters because civil service requirements barred - practically all Indians from all but a few lowly positions.

56. See National Congress of American Indians News Bulletin, May-June, 1952, p. 2. 
conclusion vary from acre to acre: On one acre the Indian Bureau acts as a guardian of unknown heirs, as a perpetual administrator of an indivisible inheritance, and as a rent-collector for holders of claims against Indians who have long since passed away; on a second acre, where an Indian wants to graze his ponies, the Indian Bureau appears as a grazing master, securing for outside livestock operators an ever-increasing control of Indian lands by forbidding the use of the range to all Indians who are too poor to construct barbed wire fences (at least $98 \%$ of the Indian population); on a third acre, the Indian Bureau turns up with a mortgage which enables it to direct almost every movement of the Indian "owner."

Faced by hundreds of special restrictions which do not apply to their white neighbors, Indians have survived on land where white men would starve to death and under regulations which could drive men of any race to insanity. The secret of this survival may perhaps be found in the Indian's perennial and drought-resistant spirit of generosity and cooperation. Commissioners have tried in vain, as one Commissioner put it, to teach the Indian to say "I" instead of "we." "wr Their failure has been the Indian's success. And this success at cooperation is now the target of the Indian Bureau's most intense attack.

The Indian has always felt that land which he did not need or could not use should be shared with other members of his family or community. This principle of Indian preference in the leasing or sale of Indian lands is written into hundreds of tribal constitutions, ordinances, and agreements, all approved by the Indian Bureau. On February 29, 1952, Commissioner Myer issued a set of "directives" which ignore all these agreements and, as currently interpreted, effectually stop gifts of land from mother to child, sales at less than market price between Indian friends and neighbors, and donations to triles. Indians see that the upshot of all these directives is to push Indian land out of Indian hands and into absentee ownership and corporation control. From 1607 to 1933, Indian land-holdings decreased steadily from year to year. From 1933 to 1949, Indian land-holdings increased. Since then, a decrease of Indian land-holdings has again taken place. ${ }^{88}$

Even those lands that remain technically within individual Indian ownership are being rapidly turned over to non-Indian control, through Bureau

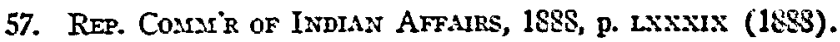

58. In the period from 1607 to 18S7, the date of the General Allotment Act, 24 Srar. 388 (1887), 25 U.S.C. $\$ 331$ (1946), Indian land-holdings were reduced from ownership of the entire continental United States to ownership of approsimately 138 million acres. By 1933, Indian land-holdings had been further reduced to a total of only 48 million acres, of which approximately 20 million acres were desert or semi-desert lands. Hcarisugs beforc House Subcommittee on Indian Affairs oso H.R. 7902, 73d Cong., 2d Sess. 15-1S (1934). Between 1933 and 1949, Indian land-holdings increased by almost 4 million aeres. ReP. SEC'Y OF THE INTERTOR, 1948, p. 380 (1949). Although official statisties have not yet been published, the Indian Bureau reports that Indian land-holdings have again deereased sinse 1949. 
repudiation of the Indian preference principle. Blackfeet Indians, for example, have been trying to get into the sheep business for many years. They are supposed to have a preference whenever Blackfeet lands are leased for sheep grazing. Only eight small Indian operators have managed to survive all the Indian Bureau's discriminatory regulations and to secure preference leases, for which they are charged $\$ 5.22$ per sheep on a three-year permit. The eleven big commercial sheep operators from Washington and Oregon who are running sheep on the Blackfeet Reservation received three-year permits from the Indian Bureau ${ }^{50}$ at the same time at $\$ 2.65$ per sheep. They paid the Indian landowners $\$ 105,860,87$ less than would have been paid to them under the terms of the so-called "Indian preference" permits.

Indians, especially returned G.I.'s, seeking to build up their little flocks and herds through the assertion of "Indian preference" rights on Indian lands, have been especially hard hit by the Indian Bureau's ruling that an Indian who secures a lease on Indian land by meeting a white man's high bid cannot take in outside cattle in his ranching operations as a white man could. The Blackfeet Indians, after almost superhuman efforts involving three appeals, two trips to Washington, and the defiance of all sorts of coercive pressure, finally succeeded in having the Indian Bureau's discriminatory rules against Indian cattlemen declared invalid by Assistant Secretary Doty. ${ }^{60}$ Nevertheless, Indians report that the Indian Bureau continues to enforce the invalid discriminations.

\section{Tribal Land}

\section{INDIAN PROPERTY}

Within the past two years, the former habit of Indian Butreau officials of disposing of Indian tribal lands without the consent of the Indians-a practice which has already resulted in more than 80 million dollars in judgments against the United States by its own courts ${ }^{61}$-generally has been reestablished as approved Interior Department practice. In May, 1951, leases were issued by the Department, without Indian consent and over the protest of the Indians concerned, covering a valuable building materials deposit on the lands of the Pueblo of San Ildefonso. On October 18, 1950, leases of valuable Blackfeet tribal grazing lands were issued by the Bureau of Indian Affairs in spite of the fact that the Blackfeet Tribe had protested against

59. On the technique by which the Bureau takes over the leasing of lands owned by individual Indians, see pages 365-7 infra.

60. Letter from Hon. Dale E. Doty, Assistant Secretary of the Interior, to Felix S. Cohen, dated March 16, 1951.

61. Among the more recent decisions granting compensation to Indian tribes for lands improperly taken by the United States are United States v. Alcea Band of Tillamooks, 329 U.S. 40 (1946), on remand, $115 \mathrm{Ct}$. Cl. 463 (1950), rev'd in part, 341 U.S. 48 (1951); Confederated Bands of Ute Indians v. United States, $100 \mathrm{Ct}$. Cl. 413 (1943), judgment entered upon stipulation, 117 Ct. Cl. 433 (1950); The Creek Nation v. United States, 2 Ind. Cl. Comm. 98 (1952). 
the proposed leases and had even taken the unusual precaution of publishing its protest in the Montana press. The Secretary of the Blackfeet Council. who attended the sale to warn lessees of the tribe's objections, was ejected from the room by the reservation superintendent. Eventually, after a series of appeals, hearings, briefs, and arguments, Assistant Secretary Doty reversed the Indian Bureau and nullified the leases. The Indian Bureau, however. then issued a press release announcing that its decisions had lueen aftirmed.

When an Indian superintendent at the Pyramid Lake Reservation attempted to protect Indian lands against white trespassers whose claims had been rejected by the federal courts, ${ }^{03}$ the superintendent was promptly ordered removed by Commissioner Myer, at the suggestion of the trespassers' legal adviser, who happened to be the senior Senator from Nevada, MIr. MIcCarran. President Truman interceded to stop the removal, but after a few weeks the superintendent, denied any support by the Interior Department, resigned and took a job protecting natives in other lands where trespassers do not have special friends in the United States Senate.

In the eyes of many contemporary Indian Bureau administrators, Indian tribal property belongs to the Indian Bureau; therefore, individual Indians should be compelled to pay for such property when they use it. The Blackfeet, Gros Ventre, and Assiniboine Indians of Montana, for example, have long supported the distribution of tribal irrigation water free of charge to indigent members of these tribes, and Congress has expressly authorized such free distribution. ${ }^{65}$ Nevertheless, the Billings Area Director forbade such water deliveries on March 16,1951. After sharp protests from the tribal councils and a formal appeal to the Department, the Area Director and Commissioner Myer were overruled on July 26, 1951, by the Acting Secretary of the Interior. ${ }^{66}$ In practice, however, the Bureau continued to ignore the overruling. 67

\section{Individual Allotments}

Dividing tribal lands into individual allotments was originally justified by the Indian Bureau on the ground that individualized property would help

62. See Associated Press dispatch from Billings, Mfontana, dated March 13, 1951.

63. Depaoli v. United States, 139 F.2d 225 (9th Cir. 1943), cort. devicd, 321 U.S. 7th (1944); United States v. Garaventa Land \& Livestock Co., 129 F.2d 416 (9th Cir. 1942).

64. See N.Y. Times, Nov. 2, 1951, p. 17.

65. 36 STAT. 270 (1910), as amended, 25 U.S.C. $\$ 3 \$ 5$ (1946).

66. Letter of Acting Secretary of the Interior R. D. Searles to Secretary of Furt Beiknap Community Council. A similar instruction was sent by Commissioner Myer ty Area Director Fickinger in respect to the similar appeal of the Blaclsfeet tribe. Nuted in letter from the Commissioner to Felix S. Cohen, dated Dee. 12, 1951.

67. A second appeal was taken on December 17, 1951, by the Ft. Bellonap Community Council from the failure of Area Director Fickinger to carry cut the order of the Acting Secretary. Again the Department ordered reversal of the Area Office rulingwith doubtful effect. 
the Indian learn to handle his own property, learn the white man's ways, and eventually develop what the Indian Bureau used to refer to as the "sacred egotism" of the white man..$^{88}$ But when the Indian began to display just these skills and attitudes, the Indian Bureau devised a system to roll back all power over Indian allotments into Bureau hands. This "recapture" device is generally called the "unit" or "power of attorney" system.

Under this system, each Indian is persuaded or, if necessary, compelled to turn over to the reservation superintendent a "power of attorney" which gives the superintendent complete authority to dispose of Indian lands for grazing purposes. What began as a more or less voluntary arrangement is now being maintained by ruthless force. Within the past two years the Indian Bureau has sent notices to Indians telling them that they will not be allowed to collect any income from their lands unless they surrender power over these lands to the agency superintendent by signing a power of attorney. Similar notices are sent to livestock operators in the vicinity who might be inclined to contract with Indians for the grazing of the operators' stock, warning them that such contracts will not be tolerated. ${ }^{60}$ The statutory authority of the Secretary of the Interior to approve or disapprove Indian leases, ${ }^{70}$ an authority originally granted to protect both Indian-lessors and their lessees from fraud and to ensure proper recording, ${ }^{71}$ is now being used to centralize the leasing of Indian lands in the Bureau itself. Thus a complete boycott is established against the individual Indian landowner. If an Indian resists these threats and attempts to use his own land for his own ponies or cattle, the Indian Bureau officials then seize his livestock or slap fines on him for alleged "trespass," even though he has not actually violated the trespass laws of the state. Eventually, in about 98 cases out of a hundred, the Indian gives up the unequal battle, signs a power of attorney, and loses all control over, or interest in, what is supposed to be his individual allotment. Once this stage has been reached, Indian Bureau officials have millions of acres of valuable grazing lands to dispose of virtually as they please.

Handing out valuable lands for free grazing by lambs owned by big outof-state sheepowners was one of the Burean practices against which the Blackfeet Indians particularly protested. Indian land has been disposed of collusively at bargain rates to Bureau employees and their friends. Indeed,

68. Rep. Comm'R of Indian AfFairs, 1885, p. 135 (1885).

69. Copies of such a notice have been submitted by the Oglala Sioux Tribe to Under Secretary of the Interior Searles under date of June 27, 1952. Compare Rep. Coum's of INDIAN AFFaIRs, 1948, p. 388 (1948) : "Revised regulations were issued last year permitting an individual Indian landowner to lease his own land and that of his minor children and to collect the lease rentals directly from his client." To the same effect is an unpublished speech by Acting Commissioner Zimmerman before the Home Missions Council on Jan. 12, 1949.

70. The relevant statutes are collected and discussed in CoHen, Handrook 227-9.

71. See White Bear v. Barth, 61 Mont. 322, 203 Pac. 517 (1921). 
despite an expose by the Portland Oregonian ${ }^{72}$ of a giant fraud in the disposal of Indian timber lands, under which a tract worth $\$ 400,000$ was sold for two checks, one of $\$ 135,000$ to the original Indian owner, and one of $\$ 25,000$ to an agent for interested Bureau employees, the Bureau official responsible for approving the transaction was continued in office.

The Indian Bureau defends this operation of private lands by Bureau officials on the ground that Government operation of large units is more efficient than individual operation of small farms, and more conducive to conservation. (The same arguments are used in Russia and China.) In malsing this argument, the Indian Bureau not only disregards the constitutional rights of the Indians concerned, but also indulges in the expectation that its employees will always have only the interests of the Indian landowners at heart. Experience shows that this expectation is highly unrealistic.

\section{Tribal Incone}

For many years the Interior Department backed the concept that Indian tribes should be allowed to spend their own earnings without let or hindrance from federal officials. ${ }^{73}$ Under Commissioner Myer's administration every bill introduced in Congress for this purpose ${ }^{74}$ has been opposed by the Interior Department, on the ground that Indians are "not yet ready" to spend their own money. In some instances, Bureau officials have gone even further. Thus the Blackfeet Tribal Council, which had a limited jurisdiction over some of its own earnings and had done its banking at the First National Bank of Browning, Montana, was peremptorily ordered on June 6, 1950, to deposit all funds in excess of $\$ 5,000$ with the Agency Superintendent. When the Tribal Council stood its ground and refused to obey this legally unauthorized order, the Indian Bureau backed down.

Why Bureau employees want to keep a stranglehold on Indian income is not difficult to understand. So long as they retain this control they can insist that such Indian funds be used to pay any Bureau employee removed from the federal payroll. ${ }^{75}$ They can prevent the use of such funds for carfare in investigating or protesting government frauds and irregularities. This restriction has been placed on the funds of the Fort Bellnap Indians in Montana, the Pyramid Lake Indians in Nevada, the Jicarilla Apache Indians in New Mexico, and many other tribes which have been earning substantial incomes for themselves through the management of tribal cattle herds, tribal stores, or other commercial enterprises.

72. Portland Oregonian, Jan. 25, 1952; N.Y. Times, Feb. 2, 1952.

73. See notes 117-122 infra.

74. H.R. 1936 (Rep. D'Ewart), H.R. 2124 (Rep. Mansfield), S. 745 (Sens. Mirray and Ecton), H.R. 6672 (Rep. Patten), all in S2d Cong., 2d Sess. (1952).

75. Among the tribes whose funds have been used in recent years to pay for clerls who were dropped from federal payrolls in response to congressional appropriation cuts but who then continued at their old work are the Rosebud Sious, the Flathead, the Blacl:feet, the Oglala Sioux, and the Fort Bellnap Community. 


\section{Tribal Buildings}

By all ordinary standards of law, equity, and morality, a building constructed on Indian lands as a "gratuity" to Indians, for which Indians have subsequently been charged (through offsets against tribal recoveries in claims cases), belongs to the Indians concerned. At least theirs is the basic equity in such a building. But when the Blackfeet Indians insisted on making use of such buildings, or at least collecting the rents which are paid by the employees who live in these buildings and which government officials now put into government accounts, they were threatened by zealous Bureau employees with arrest and even, in the case of one tribal employee, with death. Eventually the Bureau agreed that the Indians have a proper equity in such buildings, ${ }^{70}$ but the Bureau is still collecting the rentals; and, notwithstanding Commissioner Myer's promises to the Blackfeet Tribe, no tribal building of any stbstantial value has yet been turned over to the Blackfeet (or, apparently, any other) tribe.

\section{Tribal Cattle}

During the drought years in the 1930's, the Government, as a measure of relief to distressed farmers, purchased drought cattle at an average price of about $\$ 12$ a head. Most of these cattle were given away free to relief clients. Under Commissioner Myer's administration, Indian tribes which received such drought cattle have been charged up to $\$ 140$ or more a head for what started out as a gift and was a gift to everybody who wasn't an Indian. The practice of making gifts to Indians and then charging the Indians for the gift was not invented by Commissioner Myer ${ }^{77}$-it runs back many decades in our Indian history-but charging Indians $\$ 140$ or more for a gift that cost the giver only $\$ 12$ is a new wrinkle on an old game.

The Blackfeet Indians wouldn't have minded being charged for the wobbly, drought-stricken cows they received as a gift. They had no objection to paying retroactive interest on these gifts. In effect, for many of these cattle, the Indian Bureau charged interest at the rate of $70 \%$ per annum. But repaying cattle loans, even at $70 \%$ interest, was worthwhile, the Blackfeet felt, since only in this way would they achieve final and complete ownership of their own cattle. What shocked the Blackfeet, however, was that in June, 1950, after they had paid back the Indian Bureau many times over for the last cow they had received, they were suddenly advised by the Indian Bureau that title to the cattle was still vested in the Bureau and that the Bureau would arrange for the disposition of the cattle as it thought best. Bitter protests at this breach

76. See The Blackfeet Nation v. United States, $81 \mathrm{Ct}$. Cl. 101 (1935), in which the construction expense of these buildings was charged as an offset against a tribal recovery.

77. See note 76 supra. See also The Warm Springs Tribe of Indians of Oregon v. United States, $103 \mathrm{Ct}$ Cl. 741 (1945); The Indians of California v. United States, $98 \mathrm{Ct}$. Cl. 583 (1942), judgment entered upon stipulation, 102 Ct. Cl. 837 (1944); The Assiniboine Tribe of Indians v. United States, 77 Ct. Cl. 347 (1933). 
of faith were completely futile. The Chairman of the House Interior Appropriations Subcommittee, Representative Michael Irirwan, declared that he "will not believe" that "this Government, your Government, and my Government" would do any such thing. ${ }^{\text {T8 }}$ But when the Indian Bureau itself supplied facts and figures confirming the charge, ${ }^{70}$ the House Committee quiclily dropped the subject.

Many other tribes, especially in the Montana-Dakota area, have had similar experiences with the Indian Bureau cattle repayment program, and have protested vigorously, but without result. ${ }^{80}$

\section{Tribal Credit}

In 1934, the Department of the Interior went before Congress with the unusual suggestion that, since it had mismanaged Indian credit funds to a point where about $50 \%$ of its loans were in default, it vould be a good idea to turn over the management of Indian credit funds to Indian corporations. ${ }^{81}$ The thought behind this suggestion was that Indians would be more scrupulous about paying back loans from their own neighbors-as the good record of credit unions shows-than they were about paying back loans to a faraway and impersonal "Washington." Congress picked up the challenge and adopted legislation authorizing the formation of Indian tribal corporations to handle credit funds. ${ }^{82}$ The Indians organized over a hundred such corporations, which have repaid their borrowings with a net default rate of less than one-tenth of one percent. ${ }^{83}$ Within the last few years, however, the Indian Bureau has been reaching out to take back control over these funds. This drive generally makes use of unproved charges of "politics" in the handling of tribal credit funds. Behind these charges is the fact that Indian Bureau employees frequently "suggest" to Indian corporations that they lend large sums to some Indian who is more highly regarded by the Bureau than by his

78. Hearings before House Committee on Appropriations on Interim Appripriatinus for 1952, 82d Cong., 1st Sess. 1233 (1951).

79. Id. at 1261.

80. Resolution on cattle repayment, unanimnusls adopted "n Jume 23, 1951, ly telc: gates of all Montana tribes at Conference in State Capitol, called by Montana Governor John W. Bonner. Conference Proceednas 12, 13 (1951).

81. See Hearings before House Subcommitte on Indian Affairs on H.R. 7902, 73d Cong., 2d Sess. (1934) passin. An unpublished repurt on transactiuns during fizal year 1933 prepared by the Extension Division of the Indian Bureau shwwed that on June $30,1933,44 \%$ of the outstanding reimbursable indebtedness was delinquent.

82. 4 STAT. 984 (1934), 25 U.S.C. $\$ \$ 470,477$ (1946).

83. Extension Drv. of Indian Bureat, The Axnula Credit Report (1950), prepared by the Extension Division of the Indian Bureau for the fiscal year ending June 30, 1949 , shows that not a single Indian corporation or tribe was delinquent in the renayment of reimbursable indebtedness, although almost 6 million dollars had been due to the Guvernment in that year. $I d$. at $S$. The record for all Indian borrowers, including credit assinciations, cooperatives, and individuals, shows a default rate of less than $1 \%$. 
fellow tribesmen. Such suggestions are often turned down by the Indian corporations. These refusals to extend credit, according to Indian Bureau gobbledegook, are always the result of "tribal politics."

Latest step in the expansion of Bureau controls over tribal credit operations is the proposal, published in the Federal Register on January 13,1953,83a that interest rates charged tribes, which have hitherto been uniform, should hereafter be subject to the discretion of the Secretary of the Interior or the Commissioner of Indian Affairs. Originally, the tribes had been assured that, since they were taking over a federal responsibility in handling these funds, they would not be required to pay any interest on them. ${ }^{83 b} \mathrm{~A}$ "carrying charge" of $1 \%$, however, was imposed at the outset of the program. ${ }^{83 e}$ One of Commissioner Myer's first official acts was to double that levy. ${ }^{830}$ Under the new proposal, interest rates on all funds advanced to Indian tribes might vary from $2 \%$ to $5 \%$; at the same time, interest rates on federal loans to individual Indians would be raised from a uniform $4 \%$ to a range of $4 \%$ to $6 \%$. These regulations would vest in the Bureau, at its discretion, power to reward Indian tribes and individuals sympathetic to its views with low interest rates, and to penalize "unfriendly" tribes or "unfriendly" individuals by classifying them as "poor credit risks" and charging them high interest rates. Publication in the Federal Register was the only notice given of the proposed regulations, and the Indians concerned were further granted only 30 days to protest this breach of good faith.

Some Indians, in order to free themselves from federal interference in their local operations, have offered to pay back to the Indian Bureau the last dollar they ever borrowed if the Bureau would then leave them alone and let them handle their own tribal funds without Washington interference. The first response of the Indian Bureau was that such a move, however desirable, would require an act of Congress. Why a new act of Congress was needed to compel the Bureau to follow the 1934 Act, nobody ever explained. But when the Blackfeet Indians called the Bureau's bluff, and persuaded Senators Murray and Ecton and Representative D'Ewart to introduce bills ${ }^{84}$ to allow the Blackfeet to pay off their outstanding debts to the Federal Government and achieve freedom from Bureau control over tribal credit operations, the Indian Bureau opposed these bills, ${ }^{85}$ just as it has opposed every other Indian-sponsored bill designed to curtail Bureau powers during the past two years.

83a. 18 FED. REG. 256 (1953).

83b. Statement of Commissioner John Collier, Hearings before Honse Subcommittce on Indian Affairs on H.R. 7902, 73d Cong., 2d Sess. 109 (1934).

83c 25 Code Fed. Regs. §21.6 (1949).

83d. 15 FED. REG. 8023 (1950); 25 Code Fed. Regs. $\$ 21.6$ (Supp. 1950).

84. S. 2893 (Sen. Murray), S. 2908 (Sen. Ecton), H.R. 6952 (Rep. D'Ewart), alt in $82 \mathrm{~d}$ Cong., $2 \mathrm{~d}$ Sess. (1952).

85. These hearings have not been published, but transcripts are available from the House and Senate Committees on Interior and Insular Affairs. 


\section{Tribal Clains}

The fact that every year so many potentially wealthy Indians starve to death or die from diseases brought on by malnutrition is difficult to understand unless one appreciates that Indian wealth consists largely of inedible claims against the United States Treasury. A special statute enacted in 1853 prohibited all Indians from suing to collect sums due from the United States, as other citizens are permitted to do. ${ }^{s 0}$ From 1930 to 1946 , the Indian Bureau and many unofficial organizations friendly to Indian rights sought to end this discrimination. ${ }^{87}$ Finally in 1946, the Congress passed, and President Truman signed, the Indian Claims Commission Bill, ${ }^{88}$ which ends, once and for all, this discrimination against Indian tribes and establishes an Indian Claims Commission to deal with the backlog of Indian Claims that have been barred, these many decades, from the Court of Claims.

Because the Indian Bureau backed this legislation all the way, and particularly insisted that it would come forward with the factual records on which these claims might be fairly judged, ${ }^{s 0}$ the Bureau was loolied to by Indians throughout the land as the champion of a new hope of justice and economic independence. During the past two years this hope, like many other earlier Indian hopes, has crashed into small pieces.

First, a number of Indian tribes found themselves excluded from court because Commissioner Myer would not approve the only lawyers they lnew and trusted. ${ }^{30}$ Second, Commissioner Myer played a large part in blocling enactment of a bill to give Indians additional time to employ lawyers and file their claims. ${ }^{91}$ Third, since MIay, 1950, the Indian Bureau has steadfastly

86. 12 Stat. 765, 767 (1863). See note 18 sispra.

87. A bill looking forward to the settlement of all Indian claims was introlused in Congress by Representative Leavitt of Montana as early as January 6, 1930. At least eighteen similar bills were introduced in the period between 1934 and 1945.

88. 60 Stat. 1049 (1946), 25 U.S.C. $\$ \$ 70$ et seq. (1946).

89. Under Secretary Ickes, it was the custom of the Indian Bureau to go through its files and prepare "a lengthy history and discussion of the care," which was then mads" available to the Indians' attorneys as well as to the Department of Justice. Sce Statement of Harold L. Ickes quoted in Sev. REP. No. 1002, 74th Cong., 1st Sess. 4 (1935). Assistant Attorney General Blair, representing the Department of Justice, explained that it was necessary for the Government to supply the Indians' attorneys with the documentary evidence because it "does not exist anywhere else" Hcarings before Comsnistce on Expenditures in the Executive Departineints on Indian Clains, 74th Cong., 1st Sess. 25 (1935).

90. See section in text titled "The Right to Counsel," pages 355-6 sus ra.

91. During hearings before the House Subcommitte on Indian Afiairs on H.R. 2896, H.R. 3203, and H.J. Res. 210 (all bills to extend the time for filing under the Indian Claims Commission Act) Associate Commissioner H. Rex Lee, on July 3, 1951, presented a variety of reasons indicating that the requested one-year extension was unnecessary and adrocating a six-month extension limited to those tribes which sccurcd contracts approved by the Commissioner of Indian Affairs within the list six months of the allowed period for filing claims. Such a limited bill would have served no useful pur- 
refused to give Indian tribes information in Interior Department files which they need in order to present their cases properly, offering the lame excuse that such Indian requests for information amount to asking the Burealt to do research work for Indian tribes, and alleging that it is illegal for Government employees to "aid or assist" (even by telling the truth) "in the prosecution or support of claims against the United States." Indian Bureau has apparently been spying on the activities of tribal attorneys as they go through public files in the Interior Department Building and then advising opposing counsel concerning such activities in order that Indian claims may be more easily defeated. Of course, the Commissioner can always reply that disclosing information concerning the research activities of tribal attorneys helps to achieve truth, but he has made no move so far to acquaint Indian tribes, his alleged "wards," with the facts concerning similar research activities of their legal opponents in the Justice Department. ${ }^{93}$ Finally, under Commissioner Myer, the Indian Bureau has adopted the extraordinary practice of promulgating official opinions on questions before the Indian Claims Commission. ${ }^{04}$ Every such opinion rendered within the past two and a half years has been adverse to the Indians.

\section{Indian Personal Property}

Until 1952 Indians who dug turquoise, gravel, or potatoes out of their own lands were never under any compulsion to seek the approval of any federal official before disposing of such property. Within the past few months, however, the Indian Bureau's legal staff has developed the theory that what was once a part of the Indian's restricted real estate remains forever a part of that estate. On this basis the Bureau is now bringing suit to recover gravel dug by Indians from their own lands and sold for atomic energy development purposes.

At only one point in the past two years has the Indian's control over his personal property been somewhat enlarged. After several years of Indian protest and Indian Bureau travail, Secretary Chapman on June 27, 1951,

pose since the tribes with approved attorneys contracts were all able to file their claims within the allowed period; it was the tribes without approved contracts that were barred from redress.

92. This decision was affirmed by Assistant Secretary Dale E. Doty on September $27,1950$.

93. One of the reasons for refusing to give the Sac and Fox Indians information which they requested from Interior Department files was that giving such information would amount to "expressing opinions on legal questions which are committed to the Indians Claims Commission for determination." Decision of Assistant Secretary Dale E. Doty, September 27, 1950.

94. Examples of recent cases in which the Government introduced opinions of the Indian Bureau in an effort to defeat the claims of the Indians are: The Delaware Tribe v. United States, Nos. 27A and 241, Ind. Cls. Comm., March 31, 1952; Cherokee Freedmen v. United States, 2 Ind. Cls. Comm. 231 (1952). 
issued an order allowing adult Indians to spend their own income if the local superintendent thought them competent. The order leaves tribal or corporate income under Bureau control; it gives local Bureau agents power to spend an adult Indian's income for a variety of purposes without his consent; and it authorizes local agents to disregard court orders on guardianship and malie themselves the guardians of the funds belonging to Indian children and incompetent adults. This very limited liberalization of individual Indian money regulations is the longest step taken in two years in the direction of curtailing Bureau powers.

\section{Indian Tax Exemptions}

Indian tax exemptions are not personal to the Indian but are characteristic of certain forms of property, resting generally on a treaty or agreement promising that a piece of land would remain in Indian ownership forever. Such promises were generally part of the bargains by which most of the land of the United States was sold to the Government. Indians are periectly willing to give up their tax exemptions if the Federal Government will only give them back the consideration. At any rate, the courts have held that such promises of tax exemption create vested rights which even Congress is constitutionally bound to respect.95 Within the past three years, however, the Indian Bureau has sponsored a series of bills which unilaterally would end such tax exemptions. ${ }^{30}$ Interested Indians and their friends have vigorously protested against such bills as a violation of constitutional rights and of national honor.

\section{Indian Trust Estates}

When the Federal Government began, in 1798.'17 to malie "rugged individualists" out of Indians by dividing tribal lands among the members of the tribe, it initiated the practice of conferring upon itself a trustee's legal title to each tract so allotted. To this day, most individual Indian lands are held under trusts, generally extending for a 25-year trust period or longer. which are renewed from time to time unless the Indian himself requests termination of the trust. In the white man's world a trust estate is likely to be an estate of special value. But the Indian Bureau's current conception of a trust estate is that it is an estate belonging to an Indian in which the Indian

95. Choate v. Trapp, 224 U.S. 665 (1912). See also Morrow v. United States, 243 Fed. 854 (8th Cir. 1917); Solicitor's Opinion on Taxability and Alienability, $5 y$ Lands Dec 348, 352 (1922) ; Ops. Sol'z OF THE Dep't OF INTERIOz MI. 25737 (March 3, 1930); OPS. SOL'R OF THE DEP'T OF INTERIOR MI. 13864 (Dec. 24, 1924).

96. This appears in $\$ 6$ of the California bills cited in note 41 sitpra.

97. Reservations for the "use" of named individuals are included in the unpublished but ratified Treaty of June 1,1798, with the Oneida Nation (Archives No. 23). The "trust" formula was generally established by $\$ 5$ of the General Allotment Act of 18\$T, 24 Sist. 388 (1887), 25 U.S.C. $\$ 348$ (1946). 
has no rights that the Indian Bureau is bound to respect. In line with this notion, the Interior Department on December 29, 1951, inaugurated the policy of extending trust patents for only one year at a time, instead of 25 years, as was formerly the custom with respect to all lands not covered by the Inclian Reorganization Act of June 18, 1934, which extended indefinitely the trust period for all Indians covered by that Act. This means that every Indian holding such a one-year trust estate must live in uncertainty from year to year as to whether the trust will be renewed. A series of bills have recently been drafted under Commissioner Myer's direction and some of them have already been introduced, ${ }^{98}$ which would re-establish the infamous "forced patent" system, repeatedly condemned by Congress and the courts, ${ }^{00}$ under which an Indian, over his own energetic protest, may be stripped of the trust protection which the Federal Government has extended over his individual land holdings. Once this happens, the Indian's land is subject to taxation, levy, and execution, and experience shows that such "forced patent" lands remain in Indian ownership for only brief moments. ${ }^{100}$

\section{Indian Bureau Organization}

Underlying and emphasizing the shift of Indian policy during the past three years is a significant shift in the structure of the Interior Department and the Indian Bureau. The direction of this shift has been consistently towards ever-increasing power in the hands of Indian Bureau officials. Checks on powers formerly resting with Interior Department officials, with Congress, with the Indians themselves, and with interested civic groups, have been broken down, step by step, to a point where the Commissioner of Indian Affairs is, for most practical purposes, a law unto himself who looks nowhere but to his own will and conscience for direction.

This shift in the power structure of the Indian Bureau may be measured by analyzing (a) the Bureau's relations with the Indian tribes it purports to serve, (b) the relations of the Commissioner to his superiors and stbordi-

98. This appears in $\S 5$ of the California bills and in $\S 4$ of the Oregon bill, all cited in note 41 supra.

99. Pursuant to 34 STat. 182 (1906), 25 U.S.C. $\$ 349$ (1946), which authorized the Secretary of the Interior to issue a patent in fee simple "whenever he shall be satisfied that any Indian allottee is competent," the Indian Bureau frequently issued such patents without the consent of the Indian concerned, and often over his protest. This policy of "forced patents" was declared illegal in United States v. Nez Perce County, 95 F.2d 232 (9th Cir. 1938) ; United States v. Benewah County, 290 Fed. 628 (9th Cir. 1923); United States v. Ferry County, Wash., 24 F. Supp. 399 (E.D. Wash. 1938). By 44 STAT. 1247 (1927), 25 U.S.C. $\$ 352 a$ (1946), Congress provided for the cancellation of patents issued without Indian consent; and by 54 STAT. 298 (1940), 25 U.S.C. \$352c (1946), Congress authorized appropriations to repay to Indians taxes paid on such lands. Sce also MERun, op. cit. supra note 2, at p. 477; and CoHen, Handbook 25-6, 109, 258-9.

100. See Schmecrebier, The Office of Indian Afratrs, Its History, Activitits, and Organization 151 (1927). 
nates in the Interior Department, and (c) the Bureau's relations with the general public.

\section{Bureau Relations with Indian Tribes}

Tribal controls. Mounting evidence of the misuse of tribal funds by the Indian Bureau, brought to light by the Senate Survey of Conditions of Indians which began in 1928 under Senator Frazier and was continued under Senator Wheeler, ${ }^{101}$ inspired a series of congressional acts establishing tribal veto power over various activities of the Indian Bureau. Beginning with the Act of March 4. 1933, ${ }^{102}$ authorizing modification of timber contracts, and the . Ict of May 31, 1933,03 which gave the Pueblos of New Mexico a veto power over Indian Bureau expenditures of Pueblo funds, the formula of Indian consent was written into a long series of Indian statutes. ${ }^{104}$ Even the organic act of the Indian New Deal, the Act of June 1S, 1934, ${ }^{105}$ was by its terms inapplicable to any reservation where a majority of the Indians roted against it. In the eyes of so-called "expert administrators," provisions for Indian consent in Indian bills are subversive of clarity, good order, and authority. ${ }^{106}$

101. Hearings before a Subcominittee of the Senate Committe on Indiass Affairs pursiant to S. Res. 79, 70th Cong., 2d Sess. (1928) Fassim.

102. 47 STAT. 1568 (1933), 25 U.S.C. $\$ \$ 407 a, 407 \mathrm{~b}$ note (1946).

103. 48 StAT. $10 \$$ (1933), 25 U.S.C. \$ 331 note (1946).

104. See, e.g., the Mineral Leasing Act of 1938, 52 STAт. 347 (193\$), 25 U.S.C. $\$ \$ 396$ et seq. (1946). And see Annotations in 25 U.S.C.A. $\$ \$ 390,592,593,601,613,622$ (Supp. 1951).

105. 48 Stat. 984 (1934), 25 U.S.C. $\$ \$ 461$ et seq. (1946).

106. "The Southwest Indian News Letter, issued by the Institute of Ethnic Affairs, a research organization headed by Professor John Collier, former Indian Commissioner, had this comment on Commissioner Myer's activities in the Bureau:

'The Commissioner feels that he is being unfairly accused of engaging in a subtle attempt to enlarge and expand the control of the Bureau over Indians.

For he apparently does not comprehend the effect of: insisting that tribal governing bodies obtain special permission from him to send delegates to Washington; refusing to see some delegates when they make the long trip to the capitol, e.gl.. the 'run-aruund' given the Standing Rock Sioux; opposing, and even disdaining, budgetary recommendations submitted by the Indians; objecting to a provision which would have required the consent of the Indian tribe concerned before an Indian hospital could be transferred to any non-Indian agency; making personnel changes without consulting, and even against the wishes of, the Indians, e.g., the attempted removal of Superintendent [E.R.] Fryer [one of the two who resigned] from the Carson Agency; attempting to coerce the Indians into endorsing bureau programs without fully informing them of the plans and programming; and only half-heartedly endorsing the extension of the Indian Claims Commission, while recnmmending that the extension of time be for only six months."

N.Y. Times, Nov. 2, 1951, p. 17 . 
Not a single bill sponsored by Commissioner Myer during his term of office has contained an escape clause for Indians who might object to it, even in cases where Congress and the President have supported such an escape clause. ${ }^{107}$

Bills giving the several states the power to extend state criminal laws over Indians on Indian reservations (who are now subject to federal and tribal laws) have been introduced in Congress year after year for almost a century. and with rare local exceptions such bills have been opposed by Indians and defeated. ${ }^{108}$ As recently as 1949 , President Truman vetoed a bill that would have extended state criminal laws to the Navajo and Hopi Indians without their consent, on the ground that this bill violated "one of the fundamental principles of Indian law accepted by our Nation, namely, the principle of respect for tribal self-determination in matters of local government."100 Within the past two years Indians have waged a successful drive to have several similar bills modified to include an Indian consent clause. ${ }^{110}$ Commissioner Myer opposed this arrangement, notwithstanding the Indian Bureau's pledge of a few months earlier that "our proposal in this respect [state juriscliction] will provicle for a referendum of the Indians of a reservation before transfer becomes final."111

In place of the old Jeffersonian formula of "consent" of the governed, one finds the Indian Bureau now using the formula of "consultation."112 In practice, "consultation" means trying to persuade the Indians to go along with a Bureau program; if the effort fails, then the Bureau asks Congress to adopt the Bureau program anyway. The Commissioner's Withdrawal Memorandum of August 5, 1952, phrases the new formula in familiar terms:

“... [A]greement with the affected Indian groups must be attained if possible. In the absence of such agreement, however, I want our differences to be clearly defined and understood by both the Indians and ourselves. We must proceed even though Indian cooperation may be lacking in certain cases."

Transfer of burean powers. In 1934, Congress laid down two paths by which powers vested in the Indian Bureau could be terminated or transferred.

107. See text section labeled "Access to Hospitals," pages 358-9 supra.

108. See CoHen, Handbook 16, 147.

109. The President's veto message of S. 1407, dated Oct. 17, 1949, appears at 95 Cong. Rec. 14784 (1949). After the veto, the bill was redrafted so as to eliminate the state law and order provisions to which the Navajo had objected, and as amended wats passed and signed by the President. 64 Stat. 44 (1950), 25 U.S.C. $\$ \$ 631-640$ (Supp. 1952).

110. See proposals in Hearings before House Subcommittec on Indian Affairs on H.R. 459, H.R. 3235, and H.R. 3624, 82d Cong., 2d Sess. (1952). The House passed H.R. 459 with an Indian consent clause added to the bill. The Senate took no action; and so the problem was passed on to the next Congress.

111. Address by Acting Commissioner of Indian Affairs William Zimmerman, Jr, before Home Missions Council, January 12, 1949, p. 5.

112. Hearings, supra note 110 , at 26 . 
Under Section 17 of the Act of June 18, $193+,{ }^{113}$ and under similar provisions of law applicable in Alaska and Oklahoma, ${ }^{114}$ all Bureau powers over tribal property could be transferred to tribal corporations. Under the JohnsonO'Malley Act of $1934,{ }^{115}$ all welfare services performed by the Indian Bureau could be turned over to local state, county or municipal agencies. By the use of these two methods, the powers that had been rested in the Indian Bureau until 1934 were being diminished year by year. By 1950, at least $\$ 4$ tribes in the continental United States had received charters of incorporation. ${ }^{116}$ At least 80 of these charters provided for termination of Indian Bureau supervisory powers over leases, contracts, and other tribal economic affairs. In 78 of these 80 cases the stated period of supervision has already expired. In some cases, these supervisory powers were terminated instantly.117 In other cases, termination resulted automatically at a fixed date. ${ }^{118}$ In other cases, the Indians themselves, by popular vote, could fix the time when such supervisory powers were to expire, generally after five ${ }^{110}$ or ten ${ }^{120}$ years of corporate experience, but in some cases whenever the Indians thought the time appropriate. ${ }^{121}$ In each of these $S O$ charters, ${ }^{122}$ the Secretary of the Interior and the Commissioner of Indian Affairs voluntarily and finally relinquished any power to veto such an Indian decision.

In 1950. this process of giving up supervisory powers came to an abrupt and complete halt. On September 13, 1950, the Pueblo of Laguna asked for a corporate charter. After more than two years of petitions, letters to the Commissioner, appeals to Congress, visits to Washington, congressional committee hearings, and interviews with the Secretary, the Pueblo still has no answer

113. 48 Stat. 984 (1934), 25 U.S.C. $\$ \$ 461$ et seq. (1946).

114. 49 Star. 1250 (1936), 48 U.S.C. $\$ \S 35 \& 3,362$ (1946) (Alasisa); 49 StAT. 1967 (1936), 25 U.S.C. $\$ \$ 501-9$ (19+6) (Oklahoma).

115. 48 STAT. 596 (1934), as amended, 25 U.S.C. $\$ \$ 452-5$ (1946).

116. In addition, at least 65 tribes or assaciations in Alaska had receivel such charters.

117. See Charter of Organized Village of Kake, Alaska, ratified January 27, 1948. See also Charter of Aleut Community of St. Paul Island, Alaslan, ratified June 12, 1950 (issued by the Department of the Interior on May 3, 1950).

118. At least thirteen Oklahoma charters so provide. In every ease the period of supervision has expired.

119. At least twelve corporate charters so provide. In every case the period of required supervision has expired and further supervision is optional with the Indians concerned.

120. At least 50 corporate charters so provide. In 49 of these cases the period of required supervision has expired.

121. E.g., Charter of Ft. Belknap Indian Community, ratified August 25, 1937.

122. In addition to the termination of supervision cases noted in the preceding five footnotes, there are two charters with 15-year supervisory periods, one with a 20 -year period, and one with a fixed date for the end of supervision. All of these pericds except the 20-year period have expired. 
to its request. Apparently no other Indian group has had any greater success during the past two years. ${ }^{123}$

When Commissioner Myer was accused in April, 1951, of doing nothing to transfer authority over tribal property to the tribes concerned, he had to go back to 1948, two years before his accession to office, for an example of such termination of Bureau authority. "As recently as February, 1948," he wrote, "the last vestiges of Bureau control over the Stoclebridge-Munsee Indians of Wisconsin were relinquished."124 This statement was something of an exaggeration. The Indian Bureau still insists that these Indians may not appropriate their own funds or issue a fishing license or hire an attorney or perform any of a dozen other normal corporate activities without the Bureau's approval. But it is true that in February, 1948, the StockbridgeMunsee Band of Mohican Indians were able to get rid of a host of departmental supervisions by their own vote, pursuant to the terms of a charter issued by Secretary Ickes and Commissioner Collier in 1938. No similar charter, however, has been issued during the last two years to any other Indian tribe.

So, too, the process of delegating Bureau powers to local agencies seems to have undergone a sharp decline under Commissioner Myer. Under his predecessors, Indian Bureau education and health services had been turned over to state and local authorities wherever these authorities were willing to operate such facilities under the rather meager federal aid programs that are available. The critical field for transfer had thus moved to such services as extension work and road work. Here, however, the Commissioner has failed to take action. No new fields of service have been transferred to state atthorities since Commissioner Myer took office, despite repeated appeals by Indians for such transfers.

Two excuses are generally given for the Indian Bureau's current refusal to surrender any of its powers. One is the "all or nothing" approach.125

123. Anthony Leviero, Washington correspondent of the New York Times, wrote in that newspaper on Nov. 1, 1951:

"Lip service has been given to the ultimate goal of emancipation for approximately 435,000 Indians for many years by successive national administrations and by members of Congress. Yet today the goal seems as far away as ever.

"A survey of the situation as it is seen in policy-making Washington shows plainly that there exists no firm, definite program, no time-table for achieving the goal. Even more, there appears to be no real trend of policy, or even a vigorous drive among officials really to head for the goal." N.Y. Times, Nov. 1, 1951, p. 26, col. 1.

124. The quotation is from an unpublished answer to Cohen, Colonialism: U.S. Style, The Progressive, April, 1951, p. 16.

125. Commissioner Myer's denunciation of the "piecemeal approach" of various tribes to this problem of transfer of authority appears in his statement of March 9, 1951, in Hearings before House Appropriations Comonittee on Interior Departmant Appropria- 
When this approach is used, Indians who want to take over control of their own funds, or credits, or cattle, or supervise their local extension service, or manage their own roads department are told by the Commissioner, in effect :

"We are very glad to have you do these things, but first you must learn how to run a hospital because we want you also to talie over the reservation hospital."

To the Indians, this looks like going to a grocery store to buy cabbages and having the grocer say:

"Yes, we have some very nice cabbages and I'll be happy to sell them to you, but first you must buy a hospital."

This may be termed the Rebuff Courteous. On the reservation, if tribal lawyers are not present, Bureau employees are apt to use the Retort Churlish.

"Your councilmen are talking about doing away with the Indian

Bureau. If that doesn't stop, we're going to close down your hospital."

Bureau employees whose jobs are at stake, and who are well supplied with gasoline and expense money, are able to bring terrific pressure upon an Indian community to see that protests against Bureau extravagance are discouraged or that councilmen who voice such protests are not re-elected.

The second Bureau reply to those who urge that it transfer its authorities to local agencies is the fast buck pass to Congress: "This we would like to do, but Congress won't let us; why don't you get a law through Congress?" This approach is particularly useful when Congress is not in session. On the other hand, there is always the danger, when this approach is used, that the Indians will get a bill introduced by their representatives in Congress, in which case the Indian Bureau generally reveals its real attitude by opposing the bill. ${ }^{126}$

\section{The Indian Bureau and the Interior Department}

Departmental controls. The tendency of any government bureau to expand its power is vastly intensified when the people subject to the bureau's activities are without many of the normal avenues of protest, publicity, and legal redress. Many Secretaries of the Interior, across many decades, recognized this tendency to self-aggrandizement as particularly serious in the case of the Indian Bureau. They, therefore, required that all important Indian Bureau activities should be reviewed by the Solicitor and one of the Assistant Secre-

tions for 1952, \&2d Cong., 1st Sess. 1253 (1951). It is also elaborated in his speceh of July 25, 1951, before the National Congress of American Indians: "[A] partial or piecemeal approach to the problem ... will not work."

126. E.g., Hearings before House Subcommittce on Indian Affairs on Blaclefect LegisIation, April 15, 1952 (unpublished). 
taries of the Department. For many years a Departmental Board of Appeals was available to Indians who sought review of an unjust Indian Bureat ruling. During the period when Nathan R. Margold was Solicitor of the Interior Department a vast number of proposed Indian Bureau rulings were withdrawn before issuance because the Solicitor was able to convince the Commissioner or the Secretary or Assistant Secretary that what some Bureau official wanted to do would violate the rights of the Indians. To the credit of Commissioners Collier and Brophy and Acting Commissioner Zimmerman, it must be said that these departmental overrulings were accepted without rancor and a serious effort was made to abide by them.

During Commissioner Myer's regime a very different situation has prevailed. In almost no case has a proposed Indian Bureau ruling been disapproved before issuance. In very few cases are such rulings even submitted to departmental review. The Departmental Board of Appeals has not been convened since 1947. When an Assistant Secretary showed a disposition to correct Commissioner Myer's illegalities, the Commissioner took vigorous exception and succeeded in having his Bureau placed under another Assistant Secretary who, except on two or three very unusual occasions, refrained from interfering with Indian Bureau decisions. On those occasions when he did overrule a Bureau decision, the Bureau paid little or no attention to the overruling. ${ }^{127}$

The attitude of the Department's Solicitor to Indian Bureau decisions was fully expressed in his opinion of July 2, 1951, upholding the Indian Bureau's rejection of the Pyramid Lake Paiute Tribe's attorney contract:

"Perhaps I may venture the suggestion that, in passing upon the policy question in connection with each point, it is necessary to act in the light of two important principles. On one hand, there is the principle that the Department should foster local self-government among organized Indian tribes and, in dealing with such tribes in the exercise of the Department's power over them, should impose requirements on a tribe only when it seems necessary to do so in order to protect some important interest of the tribe or of the Government. On the other hand, there is the principle that, from the standpoint of stability of the administrative process, the head of a Department who has delegated authority and responsibility concerning a particular matter to a subordinate official ought not to overrule such official unless the latter has exceeded his authority, or has failed to conform to instructions issued by the head of the Department, or has made a grave error in judgment which is apt to have serious consequences. If the responsibility for deciding the present case rested upon me I believe that I should give the greater weight to the second of the two principles and affirm the Commissioner's action."

127. See, e.g., discussion of discriminatory rules against Indian cattlemen, page 304 supra. 
Professor Charles Black of Columbia Law School commented, "Or, to put it differently, if Indian progress to freedom collides with Departmental solidarity, choose the latter!"12s

Abolition of Secretary's Indian Advisory Committce. Recognizing that effective Departmental control over Bureau activities required some source of information independent of the Bureau itself, Secretary Krug, on January $5,19+9$, established his own Advisory Committee on Indian Affairs, which was expected to play a role similar to that of other advisory committees in petroleum, mining, and other fields of interest to the Interior Department. The persons appointed to this Committee were nearly all experts in the fiell of Indian affairs; two of them were Indians. ${ }^{120}$ The functioning of such a committee threatened to subject Indian Bureau activities to Departmental criticism. This possibility was effectively eliminated. Since the appointment of Commissioner Myer in May, 1950, neither the Secretary nor the Commissioner has ever requested advice on any Indian question from this . Advisory Committee on Indian Affairs. One of the members of the Committce has commented that the Committee membership is used strictly as window-dressing to convey the misleading impression that the Department's Indian policy is based on consultation with the groups represented on that paper committee.

In a late effort to secure advice from Indian leaders on Indian policy, Secretary Oscar L. Chapman set up a program of conferences with representatives of the larger tribal groups in the summer of 1952. As usual, the actual working-out of this program fell into the hands of the Commissioner, who made sure that a majority of the so-called Indian representatives called into Washington were picked by the Indian Bureau and not by the Indians. The conferences were thus largely attended by Indians who had been retired from tribal office because of their susceptibility to Bureau influence. Indians on the Bureau payroll or otherwise obligated to the Bureau did their best to convince Secretary Chapman that Commissioner Myer had the confidence of "right-thinking" Indians. Several tribes that were thus "represented"120

128. Black, Coinsel of Their Own Choosing, The American Indian, Fall, 1951, p. S.

129. The original membership of the Committee included: Oliver La Farge, Chairman, President of the Association on American Indian Affairs, Santa Fe, Nev Mexico; Louis R. Bruce, Vice-Chairman, New York; Ruth Mr. Bronson, Secretary, Esecutive Secretary, National Congress of American Indians; Mrark A. Dawber, Executive Secretary, Home Míissions Council of North America, Inc., New York; Jonathan M. Steare, President, Indian Rights Association, Philadelphia; E. P. Carville, former Governor and Senator of Nevada; W. Carson Ryan, Department of Education, University of North Carolina, Chapel Hill, N.C.; Clyde Kluckhohn, Department of Anthropology, Harvard University, Cambridge, Mass.; Roland R. Renne, President, Montana State College, Bozeman, Mont; Ruth Kirk, Chairman, Indian Committee, General Federation of Women's Clubs, Gallup, New Mexico; and Barry Goldwater, Phoenix; Arizona.

130. Department of Interior, Press Release, June 27, 1952, in one paragraph denie: that the Indian consultants represented their tribes, and in another paragraph lists "tho consultants and the tribes they represented." 
against their will are still seething over this manifestation of Interior's disregard of the right of Indians to be represented by delegates of their own choosing.

Area offices. One of the saving graces of the old Indian bureatcracy was that most decisions of the Bureau were made by the reservation superintendent, who had to live with the consequences of his mistakes. Even the most hard-boiled of the old gun-toting military superintendents could not help absorbing some understanding of Indian problems and Indian psychology from his daily contacts with flesh-and-blood Indians. All this was swiftly changed by Commissioner Myer. Superintendents were quietly stripped of most of their powers - particularly the power to apportion funds and to hire employees, upon which most other powers inevitably depend. These powers were vested in "area directors," far removed from Indian reservations. Originally these directors were called "district directors." 131 When these positions were disapproved by Congress, ${ }^{132}$ they were re-christened "regional directors." When Congress again objected, ${ }^{133}$ they were renamed "area directors." This indicates the effective scope of congressional review of a determined bureatcracy.

According to Indian Bureau theory, the area directors were supposed to be exercising powers delegated by the Washington officials, and the whole process was officially described as "bringing administration closer to the reservations." ${ }^{134}$ In practice, however, the area directors found it much easicr to take over authority from the reservation superintendents they were supposed to supervise than to take over authority from the Commissioner of Indian Affairs or the Secretary of the Interior. As superintendents were gradually reduced to the rank of clerks, Indians found it harder and harder to communicate their views to the Bureau. ${ }^{135}$ The protests of Indians throughout the country against area offices to date have been in vain.

131. REP. SEC'y OF THE INTERIOR, 1946, p. 352 (1946).

132. H.R. Rep. No. 2038, 80th Cong., 2d Sess. 14-15 (1948).

133. Hearings before House Appropriations Committee on Interior Department Appropriations for 1950, 81st Cong., 1st Sess. 591 (1949).

134. See Hearings before Senate Appropriations Committee on Interior Department Appropriations for 1951, 81st Cong., 2d Sess. 399 (1950).

135. Former Indian Commissioner Collier described the new situation in these terms: “... Mr. Myer claimed that the Superintendents had just as much responsibility as they have ever had. Again, the Commissioner missed the point. It is not a question of how much power the local agency has, but of how much power the Area Office possesses. To the extent that the Area Directors exercise any powers, the administration is removed to that degree from the supervision and control of the Indians. At the local agency level, the Indians may exert their political pressure directly. In Washington, the Indians may exert such pressure indirectly through their Congressmen. But there is no way in which the Indians may effectuate political decisions at 
Bureau persomel. When Dillon Myer took on the Commissionership, he assumed a responsibility for carrying out thousands of long-standing obligations of the Lnited States. obligations which are often remembered only by the Indians to whom they are due. In past decades the failure to carry out such obligations had bred lawsuits running to the hundreds of millions of dollars. ${ }^{135}$ It had bred resentments of even larger proportions. Sometimes these violations of obligations had arisen out of white contempt for Indians and Indian rights. More often, they had arisen out of invincible ignorance of the complicated web of treaties, statutes, and agreements that make up our federal Indian law. Mr. Myer, coming to this field from the War Relocation and Federal Housing Authorities and the State Department, with no prior knowledge of Indians or Indian law, badly needed the help of men who were thoroughly familiar with the intricacies of Indian administration. the commitments of the Federal Government, and the feelings of nearly half a million Indians.

Commissioner Myer adopted a course, however, which quiclily drove from the Bureau those officials who could have been of greatest service to him and to the Indians. The men in the Indian Office who knew most and cared most about Indians were summarily dismissed. Assistant Commissioner Zimmerman, after 17 years of faithful service, was swiftly replaced by a former WRA official who knew nothing of Indians. Shortly thereafter, the Bureau's Chief Counsel, Theodore $H$. Hzas, who had been largely responsible for the preparation of the comprehensive Handbool of Fedcral Indian Laze, was removed and replaced by another ex-IVRAt official. Having thus deprived himself of access to what had been the memory and the conscience of the Indian Bureau, Commissioner Myer embarked upon courses of action which led to the resignation of the key men who had been active in shifting the center of power from Washington offices to local Indian communities: Willard H. Beatty, Chief of the Branch of Education; Joseph C. MIcCasliill. formerly Assistant Commissioner and Manager of the Indian Arts and Crafts Board; Walter V. Woehilke, formerly Special Assistant to the Commissioner; E. Reeseman Fryer, Superintendent of the Nevada Indian Agency; John Provinse, Assistant Commissioner; and D'Arcy MIcNickle, the Indian Chief of the now emasculated Division of Tribal Relations. On the reservation level, some of the best of the older Indian superintendents have been pushed out

the Area Office level, other than by maling numerous expensive trips, and with the knowledge that the final decision is in the central office at Washington. The Area Offices thus do talie 'the administration of [Bureau] programs farther away from the Indians." " Southwest Indian News Letter, June-Aug., 1951, p. 9.

136. See, e.g., cases cited in notes 61 and 77 supro. There are now pending bofore the Indian Claims Commission more than 350 claims against the United States filed by Indian tribes. Almost all of these are based upon allegedly illegal, inequitable, or dishonorable acts of Indian Bureau officials. 
of the service; some have retired; increasingly their places have been taken by former detectives and prison wardens. ${ }^{137}$

\section{The Indian Bureau and the Public}

Secrecy. For a good many years prior to 1950 , the Interior Department pursued a "goldfish bowl" policy in Indian affairs. Indians and their attorneys, interested civic organizations, students and scientists, were all welcome to participate in conferences, to examine files and documents, and to discuss proposed policy statements and regulations in advance of their promulgation. In fact, special efforts were made to induce such consideration and discussion of difficult problems, and proposed regulations of importance were ustally sent out to all interested groups with a request for comment prior to the final decision on their issuance.

Under Commissioner Myer this practice was quickly changed. Proposerl policy statements and regulations were no longer submitted to Indians or other interested bodies for prior consideration. ${ }^{138}$ Several long-established organizations, for example, which had given much helpful advice to several of Commissioner Myer's predecessors, urged Mr. Myer to hold up the promulgation of his proposed policy statement of November 9, 1950, on Indiatn attorney contracts until the problems raised by the proposed statement cot1d be fully thrashed out. The offer was instantly rejected. ${ }^{130}$

Intelligent criticism of public affairs depends to a large extent upon public access to the facts. Commissioner Myer has withdrawn from public scrutiny the facts upon which public appraisal of his administration must largely rest. For example, the funds held in the United States Treasury to the credit of Indian tribes were a matter of public record until 1951, when requests by various Indian tribes, through their regular attorneys, for such information

137. Thus a superintendent suspected of being too "soft" (i.c., sympathetic) to the Indians and Eskimos of Alaska was replaced by a former F.B.I. agent, and a superintendent suspected of being too "soft" towards the Blackfeet Indians of Montana was replaced by a former warden of a W.R.A. detention camp.

138. The drastic change in Interior Department policy in extending trust periods on individual Indian lands for only one year instead of twenty-five, for example, was consummated without prior notice to the Indian tribes concerned or to the various civic organizations interested in such matters. See text discussion under the section marked "Indian Trust Estates," pages 373-4 supra.

139. Among the organizations which appealed to the Commissioner of Indian Affairs and the Secretary of the Interior for an opportunity to be heard before the new policy was promulgated was the Association on American Indian Affairs, which wired its appeal to Secretary Chapman on November 3,1950, and mailed a more detailed statement to the Secretary on November 8, 1950. Secretary Chapman referred the matter to the Assistant Secretary of the Interior in charge of the Indian Bureau, who urged Commissioner Myer to hold off the contemplated policy statement; but the Commissioner declined to follow this advice. 
were refused by Commissioner Myer on a curious diversity of grounds. ${ }^{130}$ Similarly, Commissioner Myer's memorandum of August 5, 1952, addressed to "All Bureau Officials," advocating legislative cancellation of treaty obligations and other trust obligations towards Indian tribes, was still being withheld from public view seven weeks after its issuance.

During Commissioner Myer's administration more than a score of Indian tribes ${ }^{\mathbf{1 4 1}}$ asked the Interior Department for a full accounting of their funds. Each of these requests was refused. On May 27, 1952, the Indian Claims Commission unanimously held that the refusal of such information was illegal. ${ }^{142}$

Bureau reaction to criticism. An incidental, if not intended, consequence of draping iron curtains around traditional sources of public information is to make informed criticism of governmental activities both difficult and suspect. Since 1950, practically all informed criticism of Indian Bureau operations has been answered by attacks on the personal integrity of the critic or his informants.

Three days before the proposed attorney regulations were rejected by Secretary Chapman, Commissioner Myer described criticism of the proposals as "a campaign of defamation and distortion which was started by a few individuals who have attempted to becloud the real issues."143 Before Congress turned down his proposed Indian Police Bill, the Commissioner described criticism of the bill as "vicious misrepresentations."144 Indian resolutions calling attention to corruption and waste in the Indian Bureau he has described as the work of scheming attorneys, notwithstanding the testimony of the Indians concerned that lawyers had nothing to do with the resolutions. ${ }^{145}$

140. Three different reasons for not supplying such information are given in the letter of Executive Officer Greenwood tu Felix S. Cohen, dated April 20, 1951, and the letter of Commissioner Miyer to Senator Hayden, dated May 15, 1951.

141. Such requests were made by the Pueblos of San Ildefonso, Santo Domingo, Santa Clara, Taos, and Nambe, in New Mexico; the Absentee Delaware, Eastern Shawnee, Peoria, Ponca, Potawatomi, Ottawa, Miami, Sac and Fox, and Iowa, in Ollahoma; the Hualapai and Papago of Arizona; the Yuma Tribe of California; the Kiclapoo, Sae and Fox, and Iowa, in Kansas and Nebraska; the Six Nations of Nev York; the Sac and Fox of Iowa; and the Fort Belknap Community of MIontana.

142. "In its dealings with the tribe," the Commission held, "the defendant liept the only records of these transactions as a self-imposed duty to its illiterate and incompstent wards and thereby became accountable to them for the manner in which it discharged its treaty, and other assumed and Congressionally imposed obligations." Iowa Tribe v. United States, 2 Ind. Cls. Comm. 167 (1952).

143. Statement of Commissioner Myer at hearings befure a Subcommittee of the Senate Committee on Interior and Insular Affairs, Jan. 21, 1952 (unpublished).

144. See note 47 supra.

145. One such charge by Commissioner Mfyer appears in Hearings before Subconmittee of House Appropriations Conmittee on H.R. 3790 , 82d Cong., 1st Sess. 1264 (1951). A specific denial of this charge by the Indians concerned appears in Hearings before 
So, too, the Commissioner's numerous letters to members of Congress who report Indian grievances, to editors who criticize his activities, and to thousands of private citizens who have voiced complaints concerning Bureau delays and mistakes, regularly charge that the Bureau's critics are either themselves dishonest or the dupes of dishonest Indian lawyers. Thousands of pages' worth of such personal attacks have been circulated at Government expense all over the United States. ${ }^{146}$ Of course, occasionally Commissioner Myer is caught in a misstatement and is forced to apologize or retract. ${ }^{147}$ This, however, does not deter his subordinates from continuing to circulate such misstatements. ${ }^{148}$

\section{ConcLusion}

"Judges," said Holmes, "are apt to be naif, simple-minded men."140 This is also true of people who are not judges. Therefore, most people who are restless under regulations they resent find comfort in the assurance that the regulations are merely temporary. Sophisticated administrators know this and are apt to use the slogans of "liquidation" whenever they are particularly anxious to expand their own regulatory powers. The classic example of this process, of course, is the vast enlargement of state powers in the Soviet Union, which is officially justified as a necessary means to bring about "the withering away of the state." An example of the same process closer to home and easier to observe is the intensive power drive which the Bureat of Indian Affairs has been carrying on under the slogan of "winding up the Indian Bureau."150

Senate Appropriations Committee on H.R. 3790, 82d Cong., 1st Sess. 2192 (1951). Similar rebuttals to Commissioner Myer's allegations of undue influence on the part of lawyers were made by the Indians during the Hearings on Proposed Regulations to Govern Indian Tribal Attorney Contracts, transcript, pp. 84-5, 119.

146. Former Secretary of the Interior, the late Harold L. Ickes, former Commissioner of Indian Affairs, John Collier, the head of the Association on American Indian Affairs, Oliver La Farge, and the former executive secretary of the National Congress of American Indians, herself an Indian and former Indian Bureau official, Mrs. Ruth Bronson, have been especially subjected to these campaigns of personal defamation at the American taxpayers' expense.

147. See Hearings before Senate Appropriations Committee on Interior Appropriations for 1952, 82d Cong., 1st Sess. 2200-1 (1951).

148. Letter from Paul L. Fickinger, Area Director, Billings, Montana, to members of the Blackfeet Tribe, dated May 9, 1951, and letter to attorney for the Blackiect Tribe, dated June 11, 1951.

149. Law and The Court in Collected Legal Papers 295 (1920).

150. In Experiment in Immortality, The Nation, July 26, 1952, the editor observad:

"This time 'winding up the Indian Bureau' has meant in practice increased control over Indians' employment of attorneys, new restrictions upon trips to Washington by Indians with grievances, curtailment of the right of individual Indians to use or lease their own lands, and denial of the rights of Indian communities to spend their own funds or even to hold free elections." 
The present Commissioner's use of "liquidation" language is particularly impressive to those who do not realize how often. in years gone by, such tall: has gone hand-in-hand with vast increases of Indian Bureau powers and appropriations. On February 15, 1951, Congressman Cannon, Chairman of the House Appropriations Committee, made public the report of an investigation of the Bureau which he had ordered, ending with the sober conclusion:

"In general terms the effectiveness of the management of the Bureau may be evaluated from the single statement that although the Bureau has, for many years. given lip service to the principle that its activities were pointed toward the eventual withdrawal of Federal supervision over Indian activities, the accomplishments have been nil.".101

The "withdrawal" policies of Commissioner Myer have been stated, word for word, by several of his predecessor Commissioners during the past 160 years and in almost every case the alleged "withdrawal" plans were followed by a vast increase in Indian Bureau appropriations. In 1917, for example. the Commissioner of Indian Affairs issued a statement almost word-for-word identical with recent statements of Commissioner Myer, and added this comment:

"This is a new and far-reaching declaration of policy. It means the dawn of a new era in Indian administration. It means that the competent Indian will no longer be treated as half ward and half citizen. It means reduced appropriations by the Government and more selfrespect and independence for the Indian. It means the ultimate absorption of the Indian race into the body politic of the Nation. It means, in short, the beginning of the end of the Indian problem."

That was said in 1917, and that year Indian Bureau appropriations jumped $74 \%$, from $\$ 17,570,284$ to $\$ 30,598,093$, according to figures published by the House Indian Affairs Committee in 1935.153

Similarly, Commissioner Myer's latest series of talks about "withdrawal"1es

151. Hearings of Subcommittee of House Appropriations Committec on Interior Department Appropriations for 1952, s2d Cong., 1st Sess. 246, 258 (1951).

152. Rep. Cossar' of Indran Afrairs, 1917, p. 4 (1917).

153. Hearings before House Indian Affairs Committee on H.R. 7781, 74th Cong., 1st Sess. 725 (1935).

One can go back even earlier and find that in 1\$37, the House Committee on Indian Affairs stated: "The present organization of the Department [referring to the Indian Department] is of doubtful origin and authority. Its administration is expensive, inefficient and irresponsible." H.R. REP. No. 474, 23d Cong., 1st Sess. 2 (1834). Appropriations for this "expensive, inefficient and irresponsible" agency (the words are those used by the House Committee) were raised the next year, 1835 , from $\$ 1,003,933$ to $\$ 1,706,444$, a raise in one year of $70 \%$.

154. The experience of one tribe with Indian Bureau withdrawal plans was graphically described at a Senate Interior and Insular Affairs Cummittee hearing, April 15, 1952:

"We have had 97 years of experience with program makers whu came uut on behalf of the Indian Bureau and sold us programs to do away with the Indian Bureau. Bacls in 1855 they sold us a 10-year program which was supposed to gut us on our feet so that 
and "liquidation" was accompanied by a request for a $70 \%$ increase in 1953 Indian Bureau appropriations over the 1952 appropriations.

In long-range terms, we find that between 1851 and 1951, a century in which the Indian Bureau kept talking about working itself out of a job and turning over responsibility to the Indians, congressional appropriations to Indian tribes decreased by approximately $80 \%$, while appropriations to the Indian Bureau (chiefly for salaries) increased by approximately $53,000 . \% .106$

What is actually involved in the so-called "liquidation" programs which the Indian Bureau is now trying to sell Congress is most clearly revealed by the California "withdrawal" bills introduced on April 10, 1952.160 The Indian groups of Southern California, according to the Chairman of the Senate Committee on Interior and Insular Affairs, "seem to be agreed that the proposed legislation would grant to the Interior Department vastly enlarged powers over California Indians and their property during the period of withdrawal."167

we would no longer need the Indian Bureau. . . . Then in 1888 they sold us another 10 . year program. ... Then in 1896 they sold us another program for our 'civilization and improvement,'... that was supposed to get us out from under Indian Bureau supervision by 1906. Then in 1907 they sold us another program-this time a 25 -year program-and the idea of that program was that after holding land in trust for us for 25 years, our Inclians would all be equipped to handle our property as individuals without further Indian Bureat restrictions. The last program that the Indian Bureau sold us was a five year plan that was inaugurated around 1922. Remember this was 6 or 7 years before the first Russian Five Year Plan, so nobody can accuse the Indian Bureau of copying from the Russians. Whatever copying was done was the other way around.

"Now if you look over all these programs for liquidating the Indian Burcau on the Blackfeet Reservation, you'll find that they all resulted actually in making the Indian Bureau a little fatter and making our own land holdings a little leaner. Now after 5 Indian Bureau programs for the Blackfeet reservation, 3 ten year programs, 1 twentyfive year program and 1 five year program, our people are left with less than $2 \%$ of the land we owned 97 years ago. The other $98 \%$ was taken by the Indian Bureau. During this period, Blackeet per capita wealth has declined by at least $67 \%$. So you gentlemen can understand why the Blackfeet are very much worried at the prospect of having the Indian Bureau send out another expert program-maker from Washington to come out and improve us any further."

155. Much of the increase represents useful services of health and education, but because of the extensive use of health and education funds for general Bureau administration, it is impossible to determine how much of this increase is actually spent for useful public services. In the Appropriation Act of February 27, 1851, Congress appropriated $\$ 121,500$ to the Indian Bureau and $\$ 751,359.80$ to the Indians. In the Appropriation Act of August 31, 1951, Congress appropriated $\$ 65,000,000$ to the Indian Bureall and $\$ 151,020$ to the Indians. In other words, Congress in 1851 gave the Indian Bureau discretionary control over the expenditure of only about $20 \%$ of Indian appropriations, and made $80 \%$ of its appropriations payable directly to the Indian tribes (either in cash or in goods or services specified by the tribes). By 1951, the portion of the Indian appropriation which was put under the discretionary control of the Indian Bureau had been raised from $20 \%$ to $9975 / 100 \%$, and the portion which was payable directly to the Indian tribes had been reduced from about $80 \%$ to less than $1 / 4$ of $1 \%$.

156. See note 41 supra.

157. Letter of Senator Joseph C. O'Mahoney, dated July 7, 1952. 
Faced with evidence that an administrator's drive for enlarged powers moves in a direction totally opposed to his professed ideals, many observers explain this inconsistency by resort to a theory of bureaucratic stupidity or hypocrisy. ${ }^{158}$ Under the influence of this theory and the traditional American penchant for blaming national ills on personal devils, there has arisen the doctrine that the only good Indian Commissioner is a dead one. But the problem of bureaucratic aggrandizement has deeper roots than one will hind who looks only to the personality or background ${ }^{159}$ of individual adminis-

158. The following divergent appraisals cannot all be true, but together they indicate the range of opinion concerning the conduct of the Indian Bureau under its present leadership:

"I think Dillon Myer is a man of unimpeachable integrity. . . . I think he is also a very able administrator, one of the most able in our government. ..." Rep. Toby Miorris, Chairman of House Subcommittee on Indian Affairs, in Hearisgs before House Subrommittee on Indian Affairs on H.R. 459, S2d Cong., 2d Sess. 54 (1952).

"A blundering and dictatorial tin-Hitler tossed a monkey wrench into a mechanism he was not capable of understanding." Harold L. Ickes (who brought Mr. Myer into the Interior Department and recommended him for the Commissionership), in New Republic, Sept. 24, 1951.

"Is he not the same gentleman who handled the Japanese detention camps and did not the military police testify that they had more trouble with him than they had with all the Japanese combined? Is not this the same Dillon Myer who bungled the housing business? Is he not the same gentleman who was in charge of this inter-American relations program and made a mess of that?

"I am not suggesting corruption or graft. However, I am not only suggesting but I am charging gross incompetence and mismanagement of this bureau. His past performance is a guarantee of inefficiency here" Statement by Rep. George H. Bender, 97 CoNG. Rec. 4374 (1951).

"I have never seen any direct proof here on the floor of the House or in the Committee of the Whole which would reflect in the slightest upon the integrity of Commissioner Dillon Aryer." Rep. John J. Rooney, in 97 Covg. Rec. 4376 (1951).

159. Commissioner Myer, for example, came to the Bureau of Indian Afiairs with a background as administrator of the War Relocation Authority, whose management of the detention camps for Americans of Japanese ancestry during World War II was characterized by Judge Denman, speaking for the Court of Appeals for the Ninth Circuit, as "unnecessarily cruel and inhuman treatment" and "in major respects as degrading as [that] of a penitentiary and in important respects, worse than in any federal penitentiary." Acheson v. Murikami, 176 F.2d 953, 954 (9th Cir. 1949). Justice Douglas, speaking for the Supreme Court, further pinpointed the racist character of W.R.A. administration, in the course of an opinion in which the Court invalidated regulations enforced by Director Myer, by declaring that the Authority had no right "to assume that the Congress and the President intended that this discriminatory action should be talien against these people wholly on account of their ancestry even though the Government 
trators. For an entire generation American teachers have been urging upon students and citizens the desirability of increased scope for the wise discretion of administrative experts. Those human beings whose lives are most directly affected by that discretion-Indians, immigrants, and government employees -are now reaping the harvest of that teaching. Changes of personnel may relieve some of the harshness and heartlessness of recent Indian Bureat assaults on Indian liberties and Indian property. But a reversal of this trend is not likely to come until Americans assume either a higher respect for inexpert human beings or a lower respect for expert administrators.

It is a pity that so many Americans today think of the Indian as a romantic or comic figure in American history without contemporary significance. In fact, the Indian plays much the same role in our American society that the Jews played in Germany. Like the miner's canary, the Indian marks the shifts from fresh air to poison gas in our political atmosphere; and our treatment of Indians, even more than our treatment of other minorities, reflects the rise and fall in our democratic faith. Here, as in other parts of the world, the undermining of that faith begins with the glorification of "expert adminis" trators" whose power-drives are always accompanied by soft music about "the withering away of the state" or the ultimate "liquidation" of this or that bureau.

It is not cynicism, but simple realism, to note that people whose freedom is being increasingly restricted want the assurance that some day, somehow, the restrictors of freedom will be liquidated or withered away. And certainly it is easier for administrators to act "efficiently" (in their own eyes) or "ruthlessly" (in other's eyes) if they console themselves with the assurance that they are helping, in the long run, to bring about a society in which coercion will disappear. What they forget, and what we need another John Maynard Keynes to remind us of, is that in the long run we are all dead, and that while the means we use may be moulded by the ends we seek, it is the means we use that mould the ends we achieve.

conceded their loyalty to this country." Ex parte Endo, 323 U.S. 283, 303-4 (1944). See also Leighton, The Governing of MEn 152 (1945); Rostow, The Japanese American Cases-A Disaster, 54 Yale L.J. 489 (1945).

An unpublished study by the Bureau of Ethnic Affairs, of which former Commissioner John Collier is president, has already described Commissioner Myer's "withdrawal" program for the Indians as "similar to the authoritarian, racist and stereotyped administration which he directed for the Japanese-Americans in World War II." In both situations, Commissioner Myer embarked upon a relocation program "emphasizing resettlement to the exclusion of other considerations and ... discouraging directly or indirectly all efforts at community building on the ground that such would . . . operate against resettlement." Ibid. In both situations, an administrator has thought he knows best where other Amcrican citizens should live and what they should do, and has arranged that the entire force of government will operate to make people do what he deems to be in their best interests. Commissioner Myer thus seems intent upon repeating, in peacetime, what has beell aptly described as "Our Worst Wartime Mistake." Rostow, Our Worst Wartime Mistake, 191 Harper's Magazine 193 (1945). 